\title{
The Efficient Improvement of Original Magnetite in Iron Ore Reduction Reaction in Magnetization Roasting Process and Mechanism Analysis by In Situ and Continuous Image Capture
}

\author{
Bing Zhao ${ }^{1,2}$, Peng Gao ${ }^{1,2, *}$, Zhidong Tang ${ }^{1,2}$ and Wuzhi Zhang ${ }^{1,2}$ \\ 1 School of Resources and Civil Engineering, Northeastern University, Shenyang 110819, China; \\ zhaob@mail.neu.edu.cn (B.Z.); tangzhidong@mail.neu.edu.cn (Z.T.); 1770805@stu.neu.edu.cn (W.Z.) \\ 2 National-Local Joint Engineering Research Center of High-Efficient Exploitation Technology for Refractory \\ Iron Ore Resources, Shenyang 110819, China \\ * Correspondence: gaopeng@mail.neu.edu.cn; Tel.: +86-024-8368-8920
}

check for

updates

Citation: Zhao, B.; Gao, P.; Tang, Z.; Zhang, W. The Efficient Improvement of Original Magnetite in Iron Ore Reduction Reaction in Magnetization Roasting Process and Mechanism Analysis by In Situ and Continuous Image Capture. Minerals 2021, 11, 645. https://doi.org/10.3390/min 11060645

Academic Editor: Mark I. Pownceby

Received: 26 April 2021

Accepted: 9 June 2021

Published: 17 June 2021

Publisher's Note: MDPI stays neutral with regard to jurisdictional claims in published maps and institutional affiliations.

Copyright: (c) 2021 by the authors. Licensee MDPI, Basel, Switzerland. This article is an open access article distributed under the terms and conditions of the Creative Commons Attribution (CC BY) license (https:/ / creativecommons.org/licenses/by/ $4.0 /)$.

\begin{abstract}
Magnetization roasting followed by magnetic separation is considered an effective method for recovering iron minerals. As hematite and magnetite are the main concomitant constituents in iron ores, the separation index after the magnetization roasting will be more optimized than with only hematite. In this research, the mechanism of the original magnetite improving iron ore reduction during the magnetization roasting process was explored using ore fines and lump ore samples. Under optimum roasting conditions, the iron grade increased from $62.17 \%$ to $65.22 \%$, and iron recovery increased from $84.02 \%$ to $92.02 \%$ after separation, when Fe in the original magnetite content increased from $0.31 \%$ to $8.09 \%$, although the Fe masses in each sample were equal. For lump ores with magnetite and hematite intergrowth, the method of in situ and continuous image capture for microcrack generation and the evolution of the magnetization roasting process was innovatively examined with a laser scanning confocal microscope (LSCM) with confocal technology and 3D morphologic technology for the first time. The naturally uneven areas, protogenetic pore edges, and magnetite and hematite edges provided active sites for reduction reactions. The microcracks gradually evolved from the lump ore surface and the edges of magnetite and hematite, which had a direct connection with the efficient improvement in ore reduction.
\end{abstract}

Keywords: original magnetite; magnetite and hematite intergrowth; magnetization roasting; microcrack evolution; magnetism conversion

\section{Introduction}

In industrial manufacturing, steel is an indispensable raw material. Steel production is used to measure the national strength and industrial level of a country [1,2]. Steel production demand has increased rapidly and steadily around the world. However, the highest-quality iron ore resources have been exploited, and reserves are insufficient. Refractory low-grade and fine particle iron ores have gradually become the main raw materials for the steel industry $[3,4]$. These refractory iron ores pose considerable challenges for conventional beneficiation methods [5-9].

Hematite $\left(\alpha-\mathrm{Fe}_{2} \mathrm{O}_{3}\right)$ is one of the most common refractory low-grade iron ores, and is widely distributed in various rocks. Due to its low grade, hematite is not considered in the steel industry without preliminary beneficiation. Many researchers have focused on the separation of hematite from gangue minerals using the froth flotation process [10-13], the reverse anionic flotation of quartz [14-16], and the magnetic separation [17-19]. After extensive theoretical and engineering exploration, magnetization roasting followed by low-intensity magnetic separation has been found to be an effective method to recover iron minerals by phase transformation of $\alpha-\mathrm{Fe}_{2} \mathrm{O}_{3}$ to $\gamma-\mathrm{Fe}_{2} \mathrm{O}_{3}$ or $\mathrm{Fe}_{3} \mathrm{O}_{4}$, achieving magnetic separation from the gangue mineral. 
Many laboratory and pilot-scale studies of iron ore magnetization roasting have been conducted, mainly focusing on hematite. Yu et al. [20] studied the beneficiation of Donganshan hematite ore fines using magnetization roasting and magnetic separation. The Fe content of the iron ore sample was $34.6 \mathrm{wt} \%$ and the main phase structures were hematite $\left(\mathrm{Fe}_{2} \mathrm{O}_{3}\right)$ and quartz $\left(\mathrm{SiO}_{2}\right)$. Under the condition of a roasting temperature of $800{ }^{\circ} \mathrm{C}$ for $8 \mathrm{~min}$, the hematite was almost completely converted into magnetite, and a higher iron grade $(65.4 \mathrm{wt} \%)$ of magnetic concentrate was achieved with iron recovery of $92.7 \%$. Tang et al. [21] recycled iron tailings through magnetization roasting and separation. The iron grade of the concentrate reached $65.91 \%$ with a recovery rate of $94.60 \%$. A pilotscale experiment of the recovery iron ore tailings from Jiuquan Iron and Steel Corporation was conducted by Sun et al. [22] using pre-concentration and suspension magnetization roasting followed by magnetic separation and flotation. The main iron phase was hematite. With the roasting temperature of $530^{\circ} \mathrm{C}$, the iron grade of obtained iron concentrate was $58.67 \%$, and the iron recovery was $57.82 \%$. Weakly magnetic hematite and siderite were converted to strongly magnetic magnetite with an average magnetic conversion rate of $81.71 \%$. A semi-industrial-scale experiment for magnetization roasting was also conducted to treat red mud with a high $\mathrm{Fe}_{2} \mathrm{O}_{3}$ content to recycle iron [23]. After roasting, the hematite and goethite phases were transformed into $\mathrm{Fe}_{3} \mathrm{O}_{4}(\mathrm{~A}), \mathrm{Fe}_{3} \mathrm{O}_{4}(\mathrm{~B})$, and $\gamma-\mathrm{Fe}_{2} \mathrm{O}_{3}$ phases. Therefore, for the beneficiation of refractory iron ores, magnetization roasting has also been proven to be a reasonable and feasible method [24].

Hematite and magnetite are the main concomitant minerals of iron ores [25]. In the past ten years, our team has focused on the magnetization roasting process for iron ores, such as hematite, limonite, and siderite [26-28]. It was found that the original magnetite in iron ore composed mainly of hematite can improve the separation index after magnetization roasting. The iron grade and recovery of roasted products increased obviously compared with only hematite in a semi-industrial-scale experiment on refractory hematite from Anshan. After the magnetization roasting process, the original hematite particles became porous after reduction to magnetite, and fresh magnetite nuclei formed preferentially at the edges of the original hematite particles [29]. Using high-resolution scanning electron microscopy, Chen et al. [30] found that microstructures of cellular porous and dendritic porous magnetite formed by hematite reduction. Strezov et al. [31], using laser light scattering apparatus, found that some cracks initiated on the surface of goethite particles with crack propagation from the surface down to $20 \%$ of the particle diameter. However, the macroscopic separation index and the microcosmic mechanism of the original magnetite optimizing the iron ore reduction effect in the magnetization roasting process were not specifically discussed by the researchers.

In this research, the improvement and reaction mechanism of original magnetite in the iron ore reduction reaction in the magnetization roasting process were explored with ore fines and lump ores. The ore fines, with different magnetite contents, were used for magnetization roasting experiments to evaluate unit mass magnetic moment, separation index, and magnetism conversion rate at different roasting temperatures, roasting times, $\mathrm{CO}$ ratios, and gas flows. The iron phase compositions and phase transformation were applied to confirm the magnetization roasting effect. Under the optimum roasting conditions, the iron grade and recovery of roasted samples confirmed the correlation of the separation index with the original magnetite content difference. Innovatively, the lump ores were placed on a thermal platform microscope. Real-time, in situ, and continuous images of the magnetization roasting process were recorded by LSCM with confocal technology and 3D morphologic technology for the first time. The transformation of hematite to magnetite and the microcrack evolution process presented the active sites for the reduction reactions. The microcrack evolution enables the direct reaction mechanism of the original magnetite, improving the iron ore reduction reaction in the magnetization roasting process. 


\section{Materials and Methods}

\subsection{Materials}

All iron ore samples used in this research were obtained from raw materials from the Qidashan dressing plant located in Liaoning Province, China. To determine the element composition of the iron ore sample, chemical multi-element analysis was conducted and the results are displayed in Table 1. The total iron content was $30.64 \%$ and the $\mathrm{SiO}_{2}$ content was $58.73 \%$. The content of other components, such as $\mathrm{Al}_{2} \mathrm{O}_{3}, \mathrm{CaO}, \mathrm{MgO}$, etc., was less than $10.63 \%$.

Table 1. The chemical multi-element analysis of the iron ore sample.

\begin{tabular}{cccccccccc}
\hline Component & $\mathrm{TFe}$ & $\mathrm{FeO}$ & $\mathrm{SiO}_{2}$ & $\mathrm{Al}_{2} \mathrm{O}_{3}$ & $\mathrm{CaO}$ & $\mathrm{MgO}$ & $\mathbf{P}$ & $\mathbf{S}$ & LOI \\
\hline Content $/ \mathrm{wt} \%$ & 30.64 & 10.49 & 58.73 & 0.23 & 1.67 & 2.41 & 0.042 & 0.026 & 0.39 \\
\hline
\end{tabular}

X-ray diffraction (XRD) results and phase analysis were used to indentify the primary minerals, as shown in Figure 1. The primary minerals were hematite $(18.74 \mathrm{wt} \%)$ and magnetite (19.7 $\mathrm{wt} \%)$. Quartz (56.35 $\mathrm{wt} \%$ ) was the main gangue mineral. The iron phase composition of the iron ore sample is presented in Table 2. The sum of Fe in hematite and magnetite was $88.42 \%$ of the total iron. The iron ore samples showed the mineral intergrowth of hematite and magnetite, with simple gangue, which were suitable for analyzing the mechanism of original magnetite improving the iron ore reduction reaction in the magnetization roasting process.

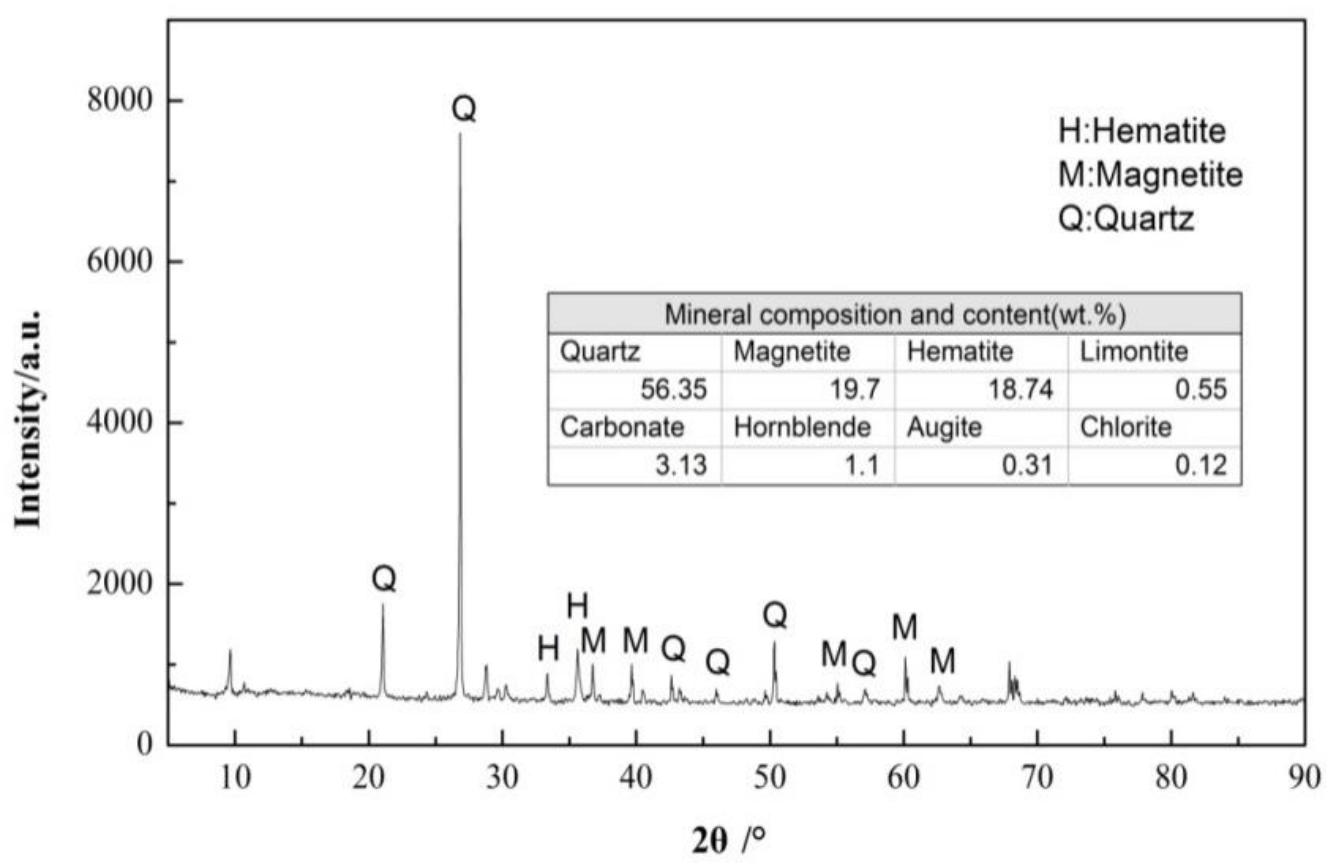

Figure 1. XRD pattern of the iron ore sample.

Table 2. The iron phase composition of the iron ore sample.

\begin{tabular}{ccccccc}
\hline Iron Phase & $\begin{array}{c}\text { Fe in } \\
\text { Magnetite }\end{array}$ & $\begin{array}{c}\text { Fe in } \\
\text { Carbonate }\end{array}$ & $\begin{array}{c}\text { Fe in } \\
\text { Hematite }\end{array}$ & $\begin{array}{c}\text { Fe in } \\
\text { Sulfide }\end{array}$ & $\begin{array}{c}\text { Fe in } \\
\text { Silicate }\end{array}$ & Total \\
\hline Content $/ \mathrm{wt} \%$ & 22.10 & 0.32 & 5.00 & 0.66 & 2.57 & 30.65 \\
Percentage $/ \%$ & 72.10 & 1.04 & 16.32 & 2.15 & 8.39 & 100.00 \\
\hline
\end{tabular}

In this research, two types of samples (ore fines and lump ore) were prepared. The ore was crushed to $-2 \mathrm{~mm}$ by a roll crushing mill (XPSF $\Phi 400 \times 250$ ), and then ground to ore 
fines $(-0.074 \mathrm{~mm})$ by a ball mill $(X M Q \Phi 240 \times 90)$. The ore fines were recombined with different magnetite ratios for single-factor experiments to explore the effect of the original magnetite improving the iron ore separation index. Low-intensity magnetic separation $(\mathrm{H}=100 \mathrm{kA} / \mathrm{m}, \Phi 240 \times 120)(-0.074 \mathrm{~mm})$ was carried out for ore fines. The iron ore fines were separated into the concentrate and the tailing. The tailing was named sample A. Sample B was a blend of the concentrate and the tailing in ratio of 1:20. Sample C was a blend of the concentrate and the tailing in ratio of 1:10. Sample D was a blend of the concentrate and the tailing in ratio of 1:7.

The chemical multi-element analysis of sample A, B, C and D is provided in Table 3. The total iron contents were $14.70 \%, 16.91 \%, 18.93 \%$ and $21.12 \%$, respectively. The iron phase compositions of sample A, B, C and D are presented in Table 4. The Fe in magnetite was $2.13 \%, 18.41 \%, 29.71 \%$ and $39.31 \%$, respectively. Therefore, the ratios of Fe in magnetite and hematite in sample A, B, C and D were about 0.1:4, 1:4, 2:4 and 3:4, respectively, which formed the original magnetite with different distributions of ore fine samples.

Table 3. The chemical multi-element analysis of sample A, B, C and D.

\begin{tabular}{ccccccccccc}
\hline Sample & Component & $\mathbf{T F e}$ & $\mathbf{F e O}$ & $\mathbf{A l}_{\mathbf{2}} \mathbf{O}_{\mathbf{3}}$ & $\mathbf{S i O}_{\mathbf{2}}$ & $\mathbf{M g O}$ & $\mathbf{C a O}$ & $\mathbf{P}$ & $\mathbf{S}$ & $\mathbf{L O I}$ \\
\hline $\mathrm{A}$ & & 14.70 & 1.03 & 0.47 & 66.17 & 5.07 & 2.81 & 0.100 & 0.021 & 3.00 \\
$\mathrm{~B}$ & & 16.91 & 2.14 & 0.40 & 62.99 & 4.79 & 2.63 & 0.098 & 0.021 & 2.98 \\
$\mathrm{C}$ & Content/wt $\%$ & 18.93 & 3.04 & 0.40 & 60.94 & 4.72 & 2.54 & 0.098 & 0.026 & 2.86 \\
$\mathrm{D}$ & & 21.12 & 4.12 & 0.38 & 58.67 & 4.29 & 2.43 & 0.089 & 0.022 & 2.62 \\
\hline
\end{tabular}

Table 4. The iron phase composition and Fe content of sample A, B, C and D.

\begin{tabular}{lccccccc}
\hline & \multirow{2}{*}{ Sample } & $\begin{array}{c}\text { Fe in } \\
\text { Magnetite }\end{array}$ & $\begin{array}{c}\text { Fe in } \\
\text { Carbonate }\end{array}$ & $\begin{array}{c}\text { Fe in } \\
\text { Hematite }\end{array}$ & $\begin{array}{c}\text { Fe in } \\
\text { Sulfide }\end{array}$ & $\begin{array}{c}\text { Fe in } \\
\text { Silicate }\end{array}$ & Total Fe \\
\hline Content $/ \mathrm{wt} \%$ & \multirow{2}{*}{$\mathrm{A}$} & 0.31 & 0.19 & 12.22 & 0.12 & 1.73 & 14.65 \\
Percentage $/ \%$ & 2.12 & 1.30 & 83.41 & 0.82 & 11.81 & 100.00 \\
\hline Content $/ \mathrm{wt} \%$ & \multirow{2}{*}{$\mathrm{B}$} & 3.10 & 0.11 & 12.00 & 0.12 & 1.51 & 16.84 \\
Percentage $/ \%$ & & 18.41 & 0.65 & 71.26 & 0.71 & 8.97 & 100.00 \\
\hline Content $/ \mathrm{wt} \%$ & \multirow{2}{*}{$\mathrm{C}$} & 5.55 & 0.13 & 10.95 & 0.12 & 1.93 & 18.68 \\
Percentage $/ \%$ & & 29.71 & 0.70 & 58.62 & 0.64 & 0.33 & 100.00 \\
\hline Content $/ \mathrm{wt} \%$ & \multirow{2}{*}{$\mathrm{D}$} & 8.09 & 0.14 & 10.72 & 0.11 & 1.52 & 20.58 \\
Percentage $/ \%$ & & 39.31 & 0.68 & 52.09 & 0.53 & 7.39 & 100.00 \\
\hline
\end{tabular}

To determine the effect of particle size distribution, sample A, B, C and D were analyzed by a laser particle size analyzer (Malvern Mastersizer 2000), and the particle size distribution curve of sample A, B, C and D are shown in Figure 2. The mean Dv(50) was $41.43 \mu \mathrm{m}$, and the standard deviation was less than $\pm 3.46 \%$ between sample $\mathrm{A}, \mathrm{B}$, $\mathrm{C}$ and D. It was confirmed that there was little difference in the particle size distribution between sample A to D, which was beneficial to compare the effect of original magnetite on improving the iron ore reduction reaction.

The lump ores were derived from the same iron ore sample to decrease experimental error. The iron ore was cut by a cutting machine. After coarse grinding by a polishing machine, the lump ores with a plate thickness of $1 \mathrm{~mm}$ and an area of $5 \mathrm{~mm} \times 5 \mathrm{~mm}$ met the requirements due to the limited room of the thermal platform microscope (Shanghaihuitong, XPL1400). $\mathrm{CO}(99.9 \%)$ and $\mathrm{CO}_{2}(99.9 \%)$ as the reductive agent and inert atmosphere were provided by Jinzhou-Quanfu Gas Co., Ltd., Jinzhou, China. 


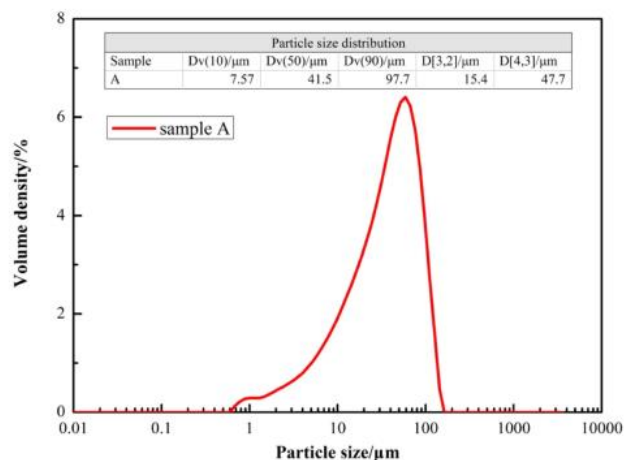

(a)

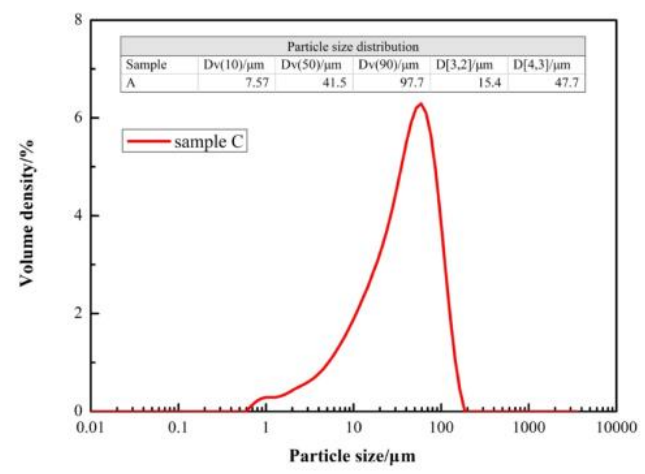

(c)

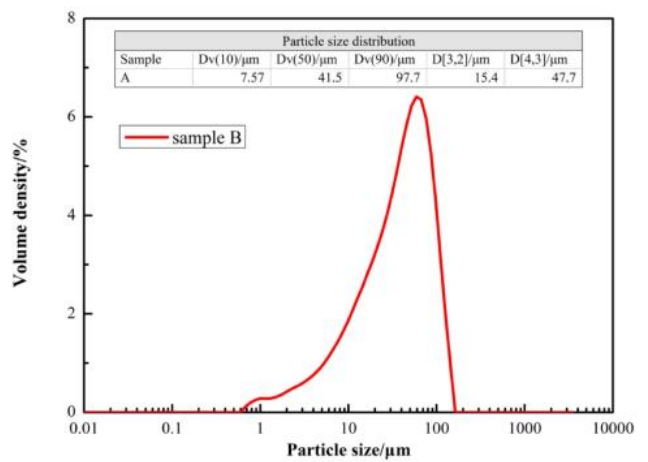

(b)

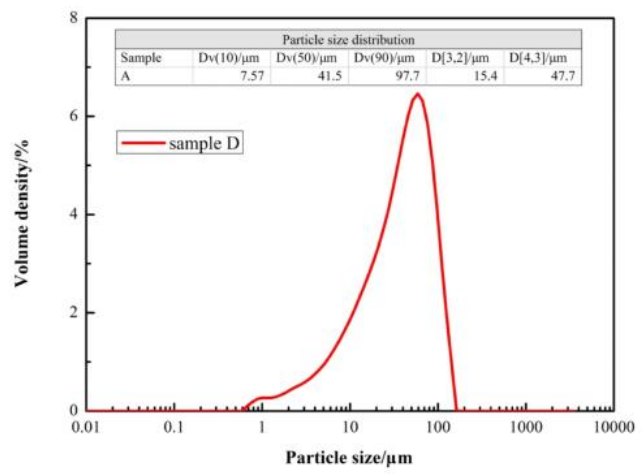

(d)

Figure 2. The particle size distribution curve of sample A, B, C and D. (a): Sample A, (b): Sample B, (c): Sample C, (d): Sample D.

\subsection{Experimental Methods}

The experimental process is illustrated in Figure 3. The ore fines of sample A to D were used as raw materials for magnetization roasting and low-intensity magnetic separation. The magnetization roasting system was composed of a roasting furnace (OTF-1200X, HFKJ Ltd.) and a gas control system. To ensure the Fe masses were equal for each sample, the ore fine masses of sample A, B, C and D were $20.00 \mathrm{~g}, 17.39 \mathrm{~g}, 15.53 \mathrm{~g}$ and $13.92 \mathrm{~g}$, respectively.

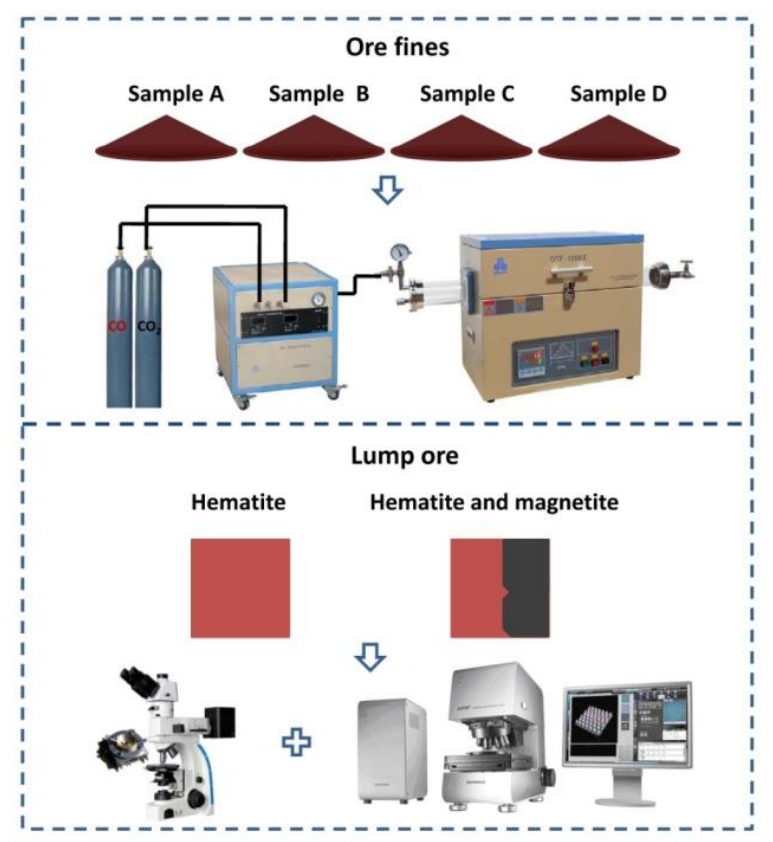

Figure 3. The experimental process of ore fines and lump ores. 
Firstly, the center of the furnace tube was heated to a predetermined roasting temperature (i.e., 500, 520, 540, 560, 580 or $600{ }^{\circ} \mathrm{C}$ ) under $\mathrm{CO}_{2}$ as the inert atmosphere. Secondly, the ore fine sample was placed quickly in the center of the furnace tube. The magnetization roasting system held the roasting temperature for the designated roasting time. $\mathrm{CO}$, as a reductive agent, was combined with $\mathrm{CO}_{2}$ in the designated ratio and aerated as the designated flow. Thirdly, the cooling stage was executed under a $\mathrm{CO}_{2}$ atmosphere, and the furnace tube was cooled to room temperature. Finally, the roasted product was removed from the furnace tube.

The polished surface of lump ores $(5 \mathrm{~mm} \times 5 \mathrm{~mm})$ was placed upward on the thermal platform. A temperature controller (AI-708P) and water-circulating pump were used in conjunction with a thermal platform microscope. The thermal platform was placed in the field of the microscope to find the correct magnification. Then, the reductive gas was aerated, and the temperature controller was started for magnetization roasting. The images of the magnetization roasting process were captured and recorded by automatic image processing software. Additionally, an LSCM (OLS 4000, Olympus Corporation, Tokyo, Japan) was used to analyze the surface morphology characteristics in the magnetization roasting images using confocal technology and 3D morphologic technology to ensure the images were authentic and vivid.

\subsection{Measurements}

After magnetization roasting, the magnetic concentrate was obtained by a magnetic separation tube (XCSG/CRS $\Phi 50 \mathrm{~mm}$, SDKS) with a magnetic field of $125 \mathrm{kA} / \mathrm{m}$ for $4 \mathrm{~min}$. The iron grade of magnetic concentrate and tailing was tested. The iron recovery was calculated. To accurately describe the effect of the original magnetite during the magnetization roasting process, the magnetism conversion rate was introduced as the evaluation index. The equation for magnetism conversion rate is shown in Equation (1).

$$
\alpha_{\mathrm{m}}=\frac{w_{m F e}^{1}-\alpha \cdot w_{m F e}^{0}}{\alpha\left(w_{T F e}^{0}-w_{S i F e}^{0}-w_{m F e}^{0}\right)} \times 100 \%
$$

where $\alpha_{\mathrm{m}}$ is the magnetism conversion rate (\%), $w_{m F e}^{1}$ is the content of Fe in the magnetic roasted product $(\%), w_{m F e}^{0}$ is the content of Fe in magnetic ore fine $(\%), w_{T F e}^{0}$ is the total iron content of ore fine (\%), $w_{S i F e}^{0}$ is the content of Fe in silicate of ore fine (\%) and $\alpha$ is the loss coefficient, which is calculated by Equation (2).

$$
\alpha=\frac{w_{\mathrm{TFe}}^{1}}{w_{\mathrm{T} F e}^{0}}
$$

where $w_{T F e}^{1}$ is the total iron content of roasted product (\%).

XRD (X Pertpro, PANalytical B.V.) with $\mathrm{Cu} \mathrm{K} \alpha$ radiation was conducted to identify the crystallographic structure of samples with a $2 \theta$ range of 10 to $85^{\circ}$. The magnetization curves of the roasted products were measured by a vibrating sample magnetometer (VSM) (JDAW-2000C\&D, YP Magnetic Technology corporation, Changchun, China).

\subsection{Thermodynamic Analysis}

Under the reductive atmosphere of $\mathrm{CO}$, the reaction equilibrium diagram between iron oxide and $\mathrm{CO}$ is shown in Figure 4. From the temperature of $400 \mathrm{~K}$ to $1400 \mathrm{~K}$ and the $\mathrm{CO}$ volume fraction of $0 \%$ to $80 \%$, the final forms of $\mathrm{Fe}$ were $\mathrm{Fe}_{3} \mathrm{O}_{4}, \mathrm{FeO}$ and $\mathrm{Fe}$. During the magnetization roasting process, hematite should be transformed to magnetite completely, which would improve the quality of roasted products. With the increase in the $\mathrm{CO}$ volume fraction, the curve entered the $\mathrm{Fe}$ and $\mathrm{FeO}$ region completely, which indicated that $\mathrm{Fe}_{3} \mathrm{O}_{4}$ was converted to $\mathrm{Fe}$ or FeO. Therefore, the roasting temperature was set to $500-640{ }^{\circ} \mathrm{C}$ preliminarily, and the $\mathrm{CO}$ volume fraction was set to $10-30 \%$ preliminarily. 


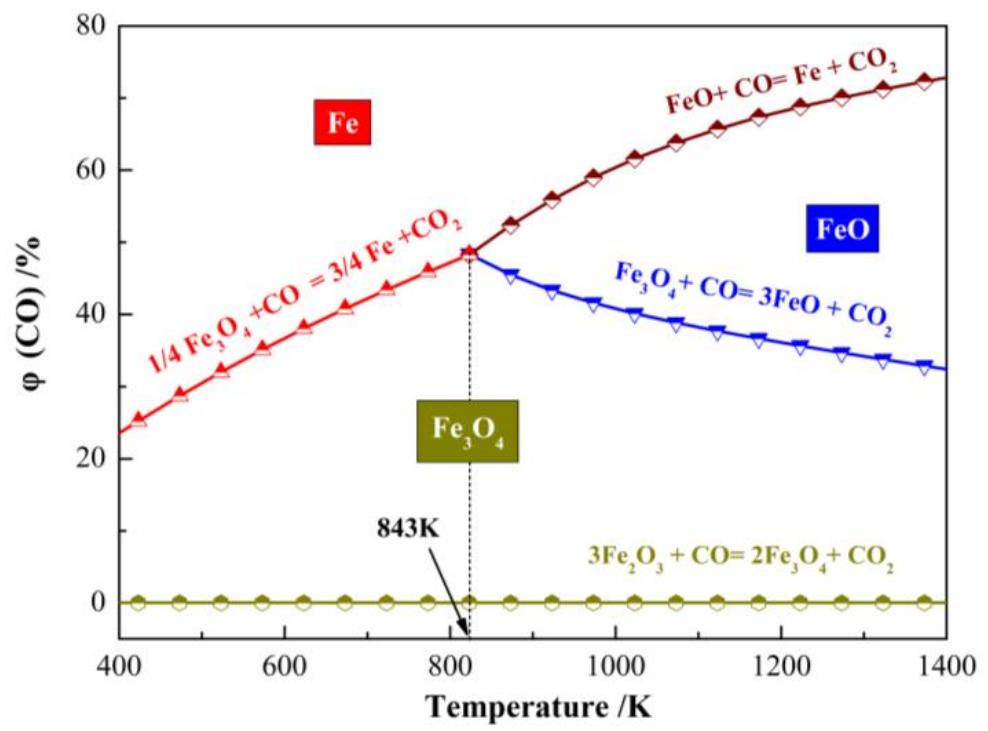

Figure 4. Diagram of equilibrium phase composition of iron oxide reduction reaction.

\section{Results}

3.1. The Effects of Magnetization Roasting Conditions on Sample A, B, C and D

\subsubsection{Effect of Roasting Temperature}

The magnetization properties have a direct relationship with the magnetite content in a sample. Under an external magnetic field, the sample exhibited magnetic characteristics, and the trend of the unit mass magnetic moment curve presented the relationship between the magnetization property and the field intensity. To analyze the effect of roasting temperature, the other conditions of the single-factor experiment were roasting time of $5 \mathrm{~min}$, gas flow of $500 \mathrm{~mL} / \mathrm{min}$ and $\mathrm{CO}$ ratio of 30\%. The curves of the unit mass magnetic moment of sample A to D are presented in Figure 5.
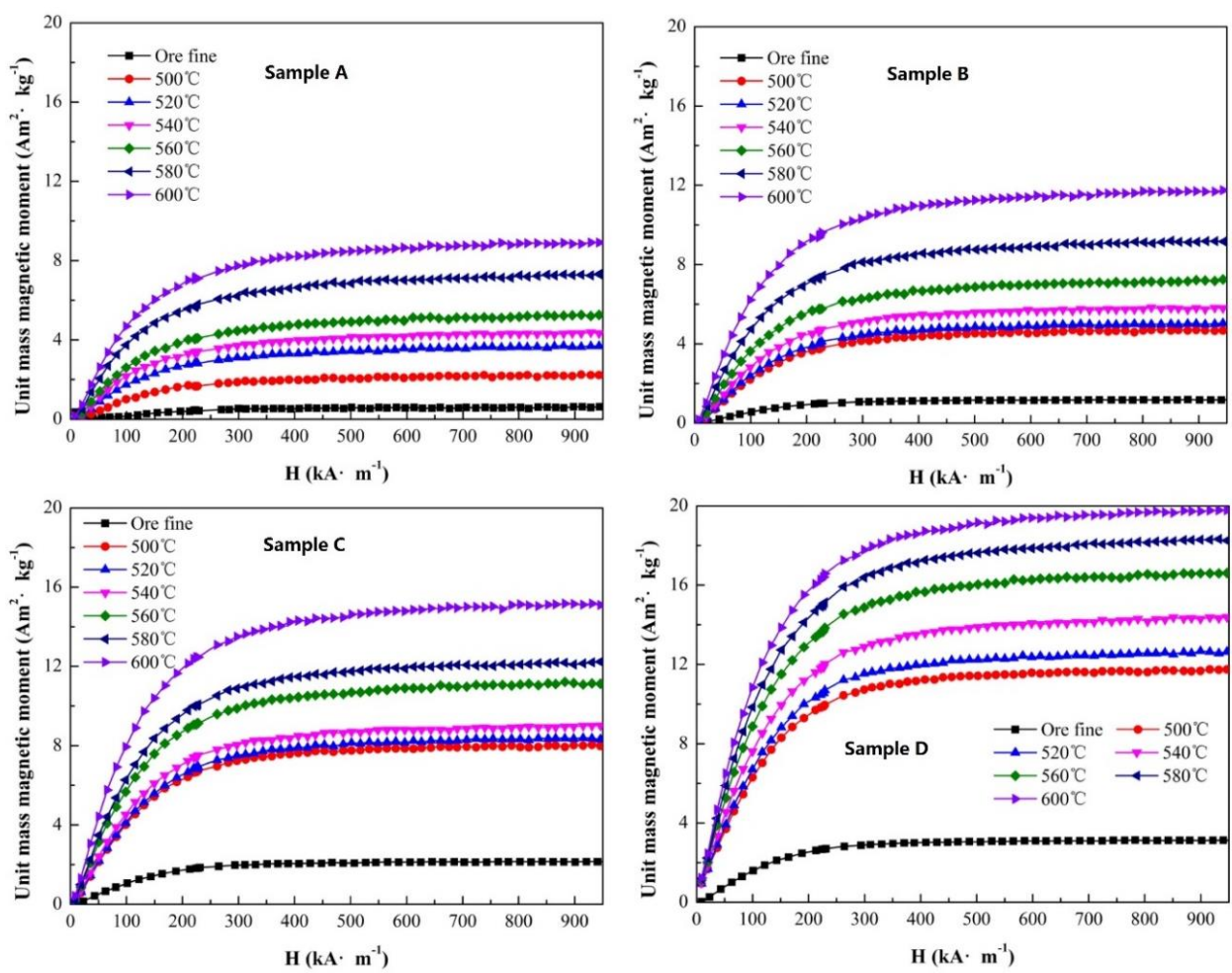

Figure 5. The unit mass magnetic moment of sample A to D with different roasting temperatures. 
The original unit mass magnetic moments of sample A to D were 0.56, 1.19, 2.14 and $3.14 \mathrm{Am}^{2} / \mathrm{kg}$, respectively, which increased with an increase in the original magnetite content in samples. As shown in Figure 5, the unit mass magnetic moment of each sample increased after magnetization roasting. Meanwhile, with an increase in roasting temperature, the unit mass magnetic moment increased obviously. The magnetization curve demonstrated a stable trend of magnetic saturation. For sample A, after roasting at a temperature of $600{ }^{\circ} \mathrm{C}$, the unit mass magnetic moment changed from 0.56 to $8.96 \mathrm{Am}^{2} / \mathrm{kg}$, and the increment in the unit mass magnetic moment was $8.40 \mathrm{Am}^{2} / \mathrm{kg}$. The maximum value of the unit mass magnetic moment was $11.74,15.21$ and $19.83 \mathrm{Am}^{2} / \mathrm{kg}$ at an external magnetic field of $950 \mathrm{kA} / \mathrm{m}$ for sample $\mathrm{B}$ to $\mathrm{D}$. It was confirmed that major weakly magnetic $\mathrm{Fe}_{2} \mathrm{O}_{3}$ transformed to $\mathrm{Fe}_{3} \mathrm{O}_{4}$ with a large unit mass magnetic moment. The increment in the unit mass magnetic moment was $10.55 \mathrm{Am}^{2} / \mathrm{kg}$ for sample $\mathrm{B}, 13.07 \mathrm{Am}^{2} / \mathrm{kg}$ for sample $\mathrm{C}$ and $16.69 \mathrm{Am}^{2} / \mathrm{kg}$ for sample D with roasting at a temperature of $600{ }^{\circ} \mathrm{C}$, although the Fe masses of each sample were equal. However, the increments in the unit mass magnetic moment of sample A to D were not uniform. Therefore, the original magnetite content of iron ore can affect the magnetization property after the magnetization roasting process obviously.

If the roasting temperature is low, the reduction efficiency will be limited, and the separation index of iron mineral and gangue mineral will be unsatisfactory. However, a higher roasting temperature will lead to the excessive reduction of iron oxide to $\mathrm{FeO}$ [32]. The effects of roasting temperature on magnetic separation for sample A to D are presented in Figure 6. The iron grade is the ratio of Fe mass to magnetic separation concentrate mass. The iron recovery is the ratio of Fe mass in magnetic separation concentrate mass to $\mathrm{Fe}$ mass in raw ore.
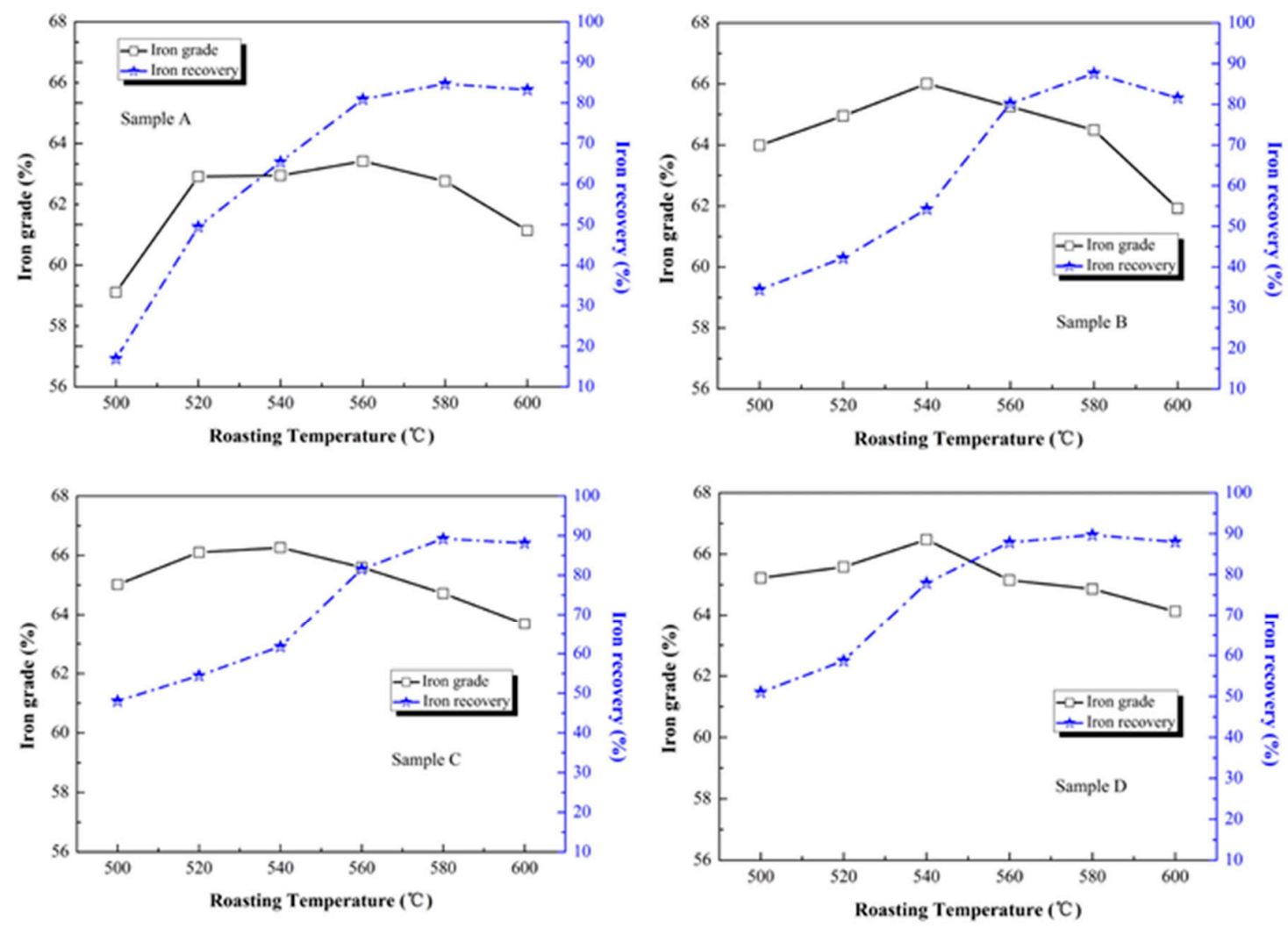

Figure 6. The iron grade and iron recovery of sample A to D with different roasting temperatures.

As shown in Figure 6, sample A had a stable iron grade of $62-63 \%$ from 520 to $580{ }^{\circ} \mathrm{C}$. The iron grade of sample $\mathrm{B}$ to $\mathrm{D}$ showed a unimodal form with a roasting temperature of 500 to $600{ }^{\circ} \mathrm{C}$. For sample B to D, the maximum values of iron grade appeared at a 
roasting temperature of $540{ }^{\circ} \mathrm{C}$, which were $66.01 \%, 66.26 \%$ and $66.47 \%$, respectively. A higher original magnetite content had a more obvious effect on the iron grade of roasted samples after low-intensity magnetic separation. The iron recovery of sample A to D increased steadily with a roasting temperature of 500 to $600{ }^{\circ} \mathrm{C}$. The max values of iron recovery appeared at a roasting temperature of $580{ }^{\circ} \mathrm{C}$. The maximum values of iron recovery were $84.72 \%, 87.60 \%, 89.22 \%$ and $89.67 \%$ for sample A to D, respectively, and the maximum values of iron recovery also increased with the original magnetite content of ore fine, which also confirmed that a higher original magnetite content improved the iron phase transformation to $\mathrm{Fe}_{3} \mathrm{O}_{4}$ and increased the separation index. According to thermodynamic analysis, the iron oxide may be reduced to $\mathrm{FeO}$ or metallic Fe with higher roasting temperature. $\mathrm{FeO}$ and metallic $\mathrm{Fe}$ had strong reducibility. The gangue minerals can easily combine with them to form pumice. The pumice has poor magnetic response, so iron recovery will decline in the magnetic separation concentrate [33].

\subsubsection{Effect of Roasting Time}

According to the comprehensive analysis of iron grade and iron recovery with different roasting temperatures in a single-factor experiment, the other experiment condition changed to roasting temperature of $580{ }^{\circ} \mathrm{C}$, gas flow of $500 \mathrm{~mL} / \mathrm{min}$ and $\mathrm{CO}$ ratio of $30 \%$ with different roasting times. The curves of unit mass magnetic moments of sample A to D are presented in Figure 7.
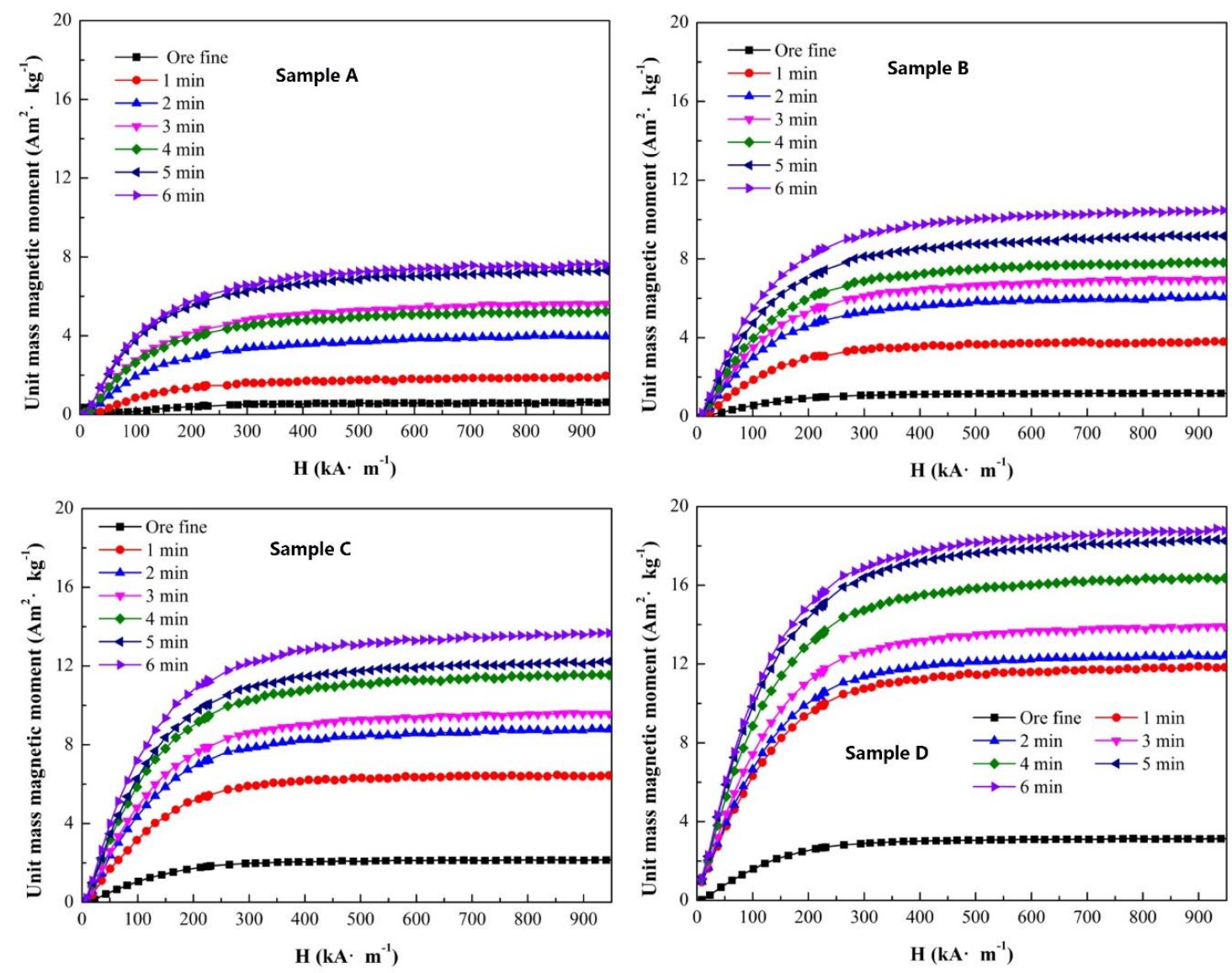

Figure 7. The unit mass magnetic moment of sample A to D with different roasting times.

The unit mass magnetic moment of each sample was strengthened with an increase in roasting time. Meanwhile, the unit mass magnetic moment of sample A to D was strengthened under the same roasting time. The effect of original magnetite content was also examined in the single-factor experiment of roasting time. The trends of the unit 
mass magnetic moment curves with different roasting times were similar to Figure 5 . The maximum values of unit mass magnetic moment were $7.66,10.50,13.67$ and $18.87 \mathrm{Am}^{2} / \mathrm{kg}$ at an external magnetic field of $950 \mathrm{kA} / \mathrm{m}$ for sample $\mathrm{A}$ to $\mathrm{D}$, respectively. The increment in unit mass magnetic moment was $7.10 \mathrm{Am}^{2} / \mathrm{kg}$ for sample A, 9.31 $\mathrm{Am}^{2} / \mathrm{kg}$ for sample B, 11.53 $\mathrm{Am}^{2} / \mathrm{kg}$ for sample C, and $15.73 \mathrm{Am}^{2} / \mathrm{kg}$ for sample D with roasting time of $6 \mathrm{~min}$. Although the Fe masses of each sample were equal, the increments in unit mass magnetic moment of sample A to D were also not uniform. The increments in unit mass magnetic moment were less than those with a roasting temperature of $600{ }^{\circ} \mathrm{C}$. It was confirmed that roasting temperature had a major effect on the magnetization property of magnetization roasted products.

During the magnetization roasting process, the roasting time plays an important role in heat and mass transfer. If the roasting time is short, the heat and mass transfer will be inefficient, which has a negative impact on the reduction reaction and magnetization process. If the roasting time is too long, the iron ore will lead to excessive reduction, which is consistent with the dissatisfactory reduction process with the higher roasting temperature. Adjusting the roasting time to a suitable range can be conducive to the reduction and magnetization process [34,35]. To optimize the roasting time, a series of roasting and separation experiments were designed with different roasting times. The effects of roasting time on magnetic separation for sample A to D are presented in Figure 8. As shown in Figure 8, the iron grade of sample A to $C$ increased and then declined during a roasting time of 1-6 min, and the peak value of iron grade appeared at a roasting time of $2 \mathrm{~min}$. The maximum values of iron grade of sample A to C were $63.53 \%, 66.24 \%$ and $65.79 \%$, respectively. The single-factor experiment of roasting time showed that a roasting time of 1-2 min could transform hematite to magnetite effectively. With the increase in original magnetite in each sample, the appropriate roasting time was reduced. The iron grade difference value of roasting time from $1 \mathrm{~min}$ to $2 \mathrm{~min}$ decreased to $5.91 \%, 3.08 \%$ and $1.52 \%$ in sample $A$ to $C$. In sample D, the iron grade declined with an increase in roasting time, and the maximum value of iron grade was $66.74 \%$. It was confirmed that if the original magnetite content is higher, the $\mathrm{Fe}_{3} \mathrm{O}_{4}$ transformation rate is also higher. This was dissimilar to the iron grade, as the iron recovery increased with an increase in roasting time in all the samples. The maximum values of iron recovery stabilized at a roasting time of $5 \mathrm{~min}$, which were $84.72 \%, 87.61 \%, 89.22 \%$ and $89.67 \%$, respectively. Therefore, the maximum level of transformation to $\mathrm{Fe}_{3} \mathrm{O}_{4}$ appeared at a roasting time of $5 \mathrm{~min}$.
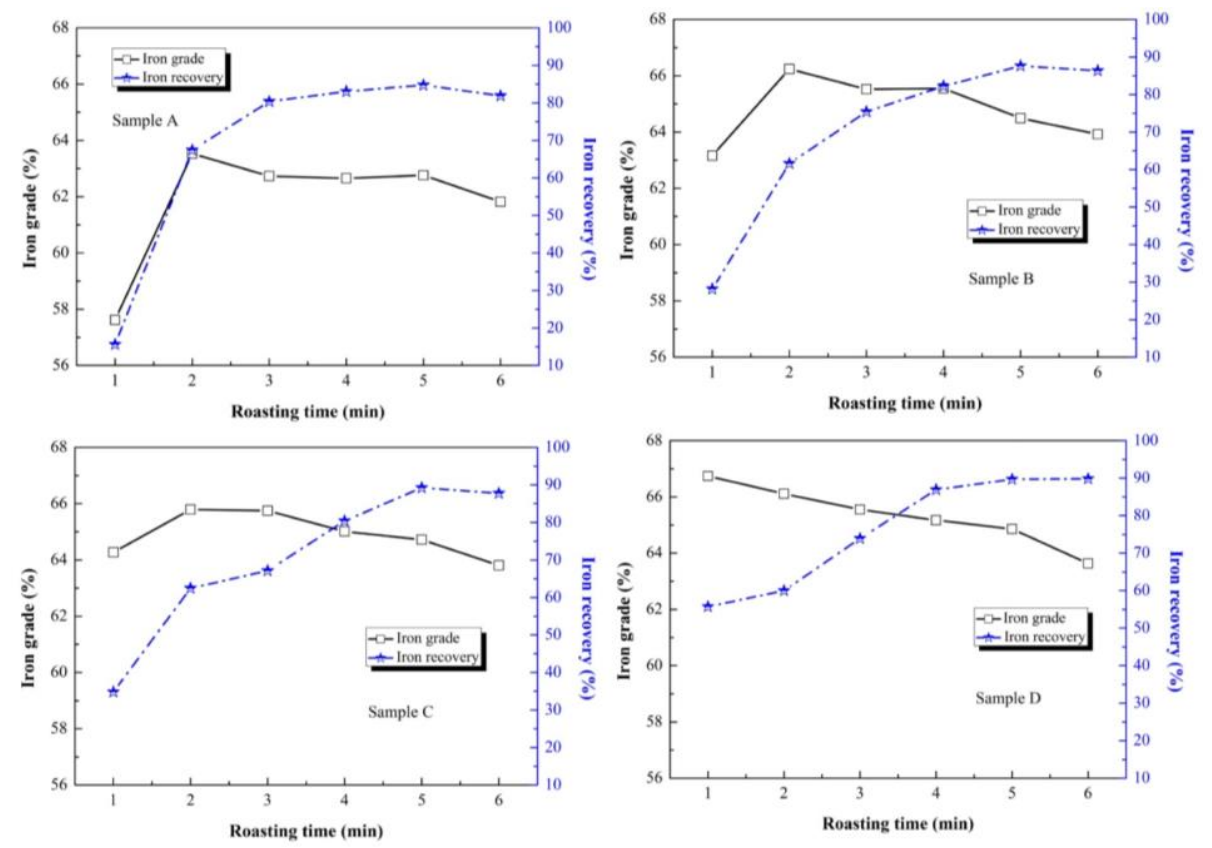

Figure 8. The iron grade and iron recovery of sample A to D with different roasting times. 


\subsubsection{Effect of CO Ratio}

In addition to the condition of roasting temperature and roasting time, the $\mathrm{CO}$ ratio is also a crucial factor in the magnetization roasting process. Insufficient $\mathrm{CO}$ impedes hematite transformation to magnetite. According to thermodynamic analysis, excessive $\mathrm{CO}$ can cause magnetite transformation to $\mathrm{FeO}$, or even $\mathrm{Fe}$. Under the experimental conditions of a roasting temperature of $580^{\circ} \mathrm{C}$, roasting time of $5 \mathrm{~min}$ and gas flow of $500 \mathrm{~mL} / \mathrm{min}$, the magnetization roasting performances with different $\mathrm{CO}$ ratios were determined and are shown in Figure 9. With an increase in the $\mathrm{CO}$ ratio, the unit mass magnetic moment increased obviously. For sample A, after roasting with a $\mathrm{CO}$ ratio of $35 \%$, the unit mass magnetic moment changed from 0.56 to $8.18 \mathrm{Am}^{2} / \mathrm{kg}$, and the increment in unit mass magnetic moment was $7.62 \mathrm{Am}^{2} / \mathrm{kg}$. The increment in unit mass magnetic moment was $9.29 \mathrm{Am}^{2} / \mathrm{kg}$ for sample B, $11.44 \mathrm{Am}^{2} / \mathrm{kg}$ for sample C and $16.69 \mathrm{Am}^{2} / \mathrm{kg}$ for sample D with a $\mathrm{CO}$ ratio of $35 \%$. The increments in unit mass magnetic moment of sample A to D were also not uniform. It was also found that the original magnetite content of a sample can affect the magnetization property when roasting with different $\mathrm{CO}$ ratios.
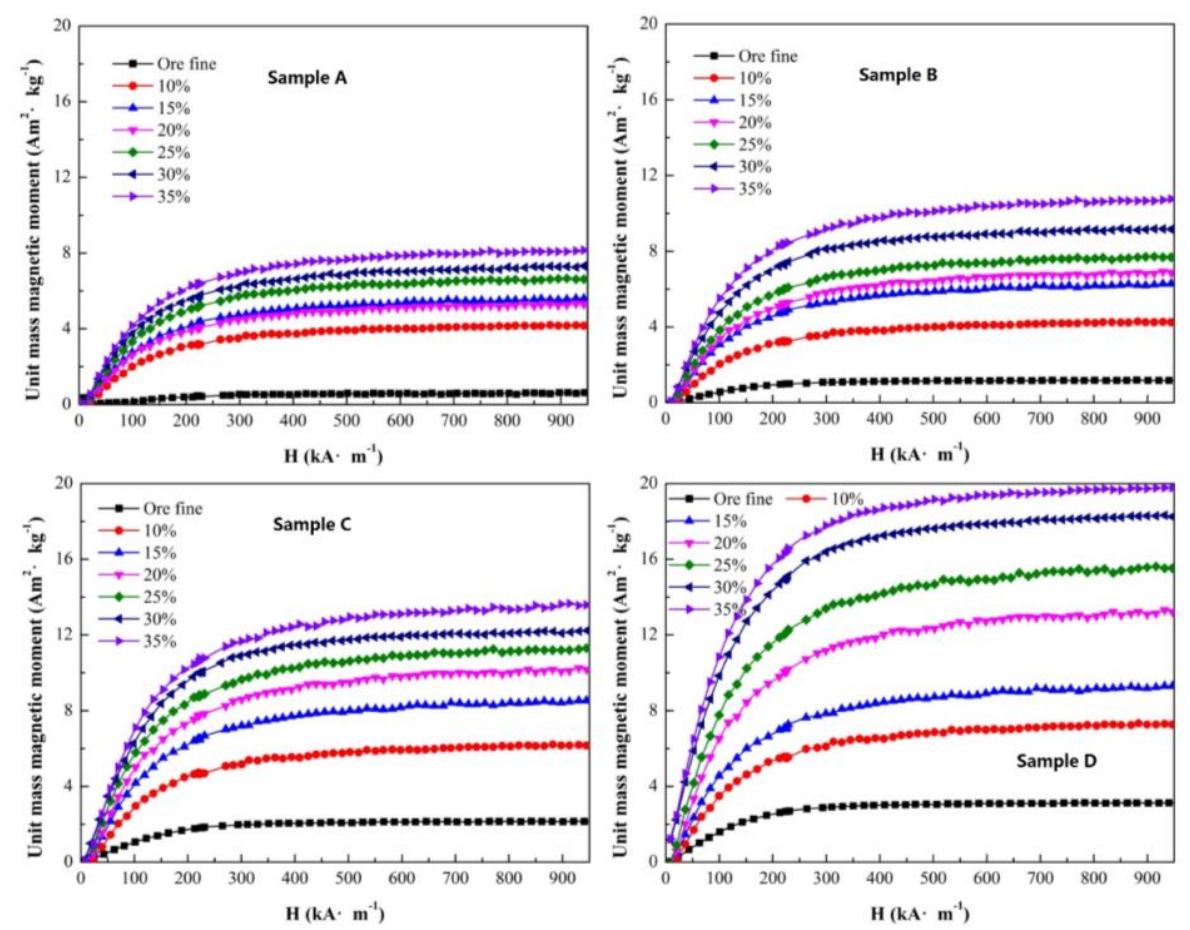

Figure 9. The unit mass magnetic moment of sample A to D with different $\mathrm{CO}$ ratios.

To determine the optimum $\mathrm{CO}$ ratio of the injection gas, a series of roasting experiments were designed with different $\mathrm{CO}$ ratios. As shown in Figure 10, the iron grade of all the samples declined with an increase in $\mathrm{CO}$ ratio. The maximum values of iron grade of all the samples were $63.39 \%, 65.52 \%, 66.01 \%$ and $64.86 \%$, respectively. When the content of original magnetite increased, the iron grade with a $35 \%$ CO ratio stabilized at $61.08 \%$ (sample A), $63.8 \%$ (sample B), $63.21 \%$ (sample C) and $64.23 \%$ (sample D). In agreement with the effect of roasting temperature and roasting time, the iron recovery increased continuously and stably when the CO ratio increased from $10 \%$ to $35 \%$. Under the appropriate $\mathrm{CO}$ ratio of $30 \%$, the iron recovery was $84.70 \%$ (sample A), $87.60 \%$ (sample B), $88.55 \%$ (sample C) and $89.68 \%$ (sample D). The increase in CO ratio increases the sufficient contact chance of the gas phase and solid phase, which accelerates the reduction of hematite to magnetite and optimizes the separation effect of magnetic concentrate [22]. The superfluous $\mathrm{CO}$, as a reductive gas, had a negative impact on magnetic separation, which caused the over-reduction of magnetite to weakly magnetic ferrous oxide. Meanwhile, the superfluous $\mathrm{CO}$ also caused reductive gas waste. 

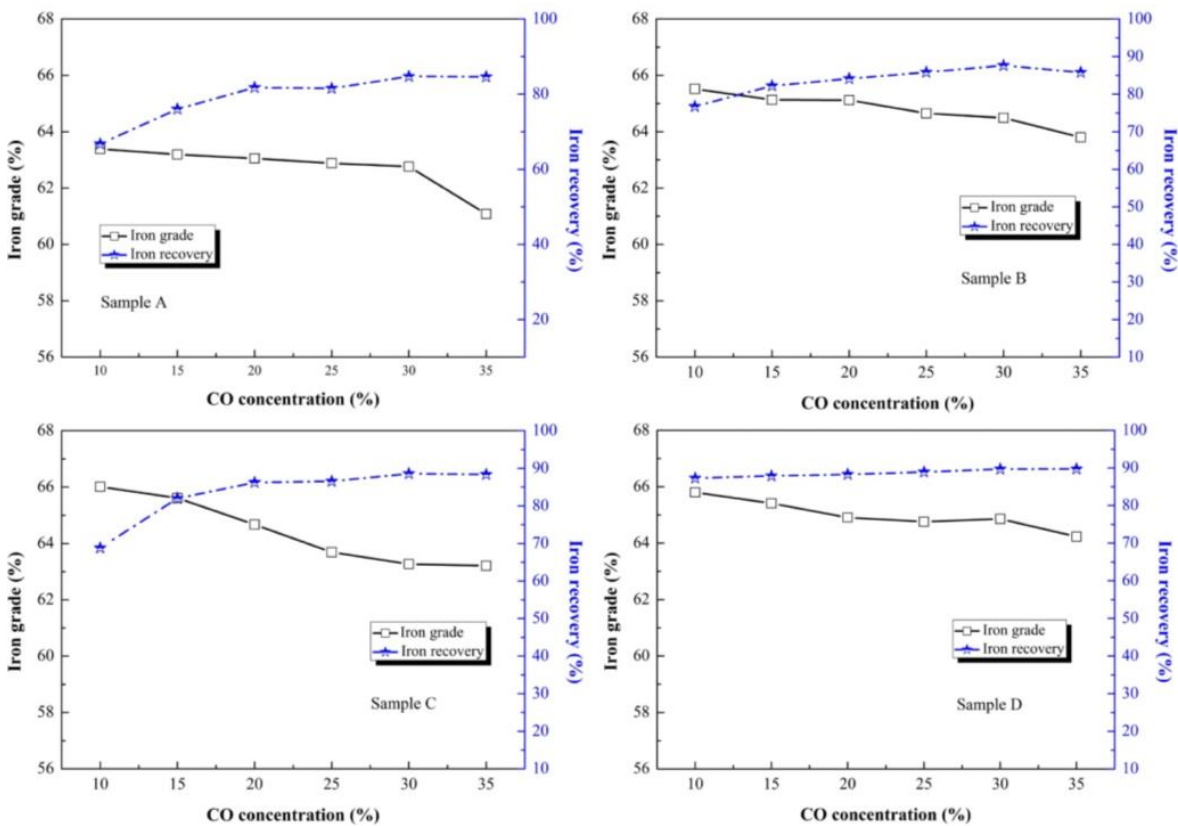

Figure 10. The iron grade and iron recovery of sample A to D with different $\mathrm{CO}$ ratios.

\subsubsection{Effect of Gas Flow}

All the samples were roasted under the conditions of a roasting temperature of $580{ }^{\circ} \mathrm{C}$, roasting time of $5 \mathrm{~min}$ and appropriate $\mathrm{CO}$ ratio of $35 \%$. The unit mass magnetic moments of sample A to D with gas flow are presented in Figure 11. For each sample, the unit mass magnetic moment stabilized within a certain range. The maximum unit mass magnetic moments were obtained with a gas flow of $350 \mathrm{~mL}$ (sample A), $300 \mathrm{~mL}$ (sample B), $400 \mathrm{~mL}$ (sample C) and $300 \mathrm{~mL}$ (sample D), not the highest gas flow. Therefore, for magnetization roasting, the reductive gas ratio and flow needed to cooperate and interact to produce the ideal reduction reaction result. As the original magnetite increased from $18.41 \%$ to $39.31 \%$, the unit mass magnetic moment presented a stepped increase.
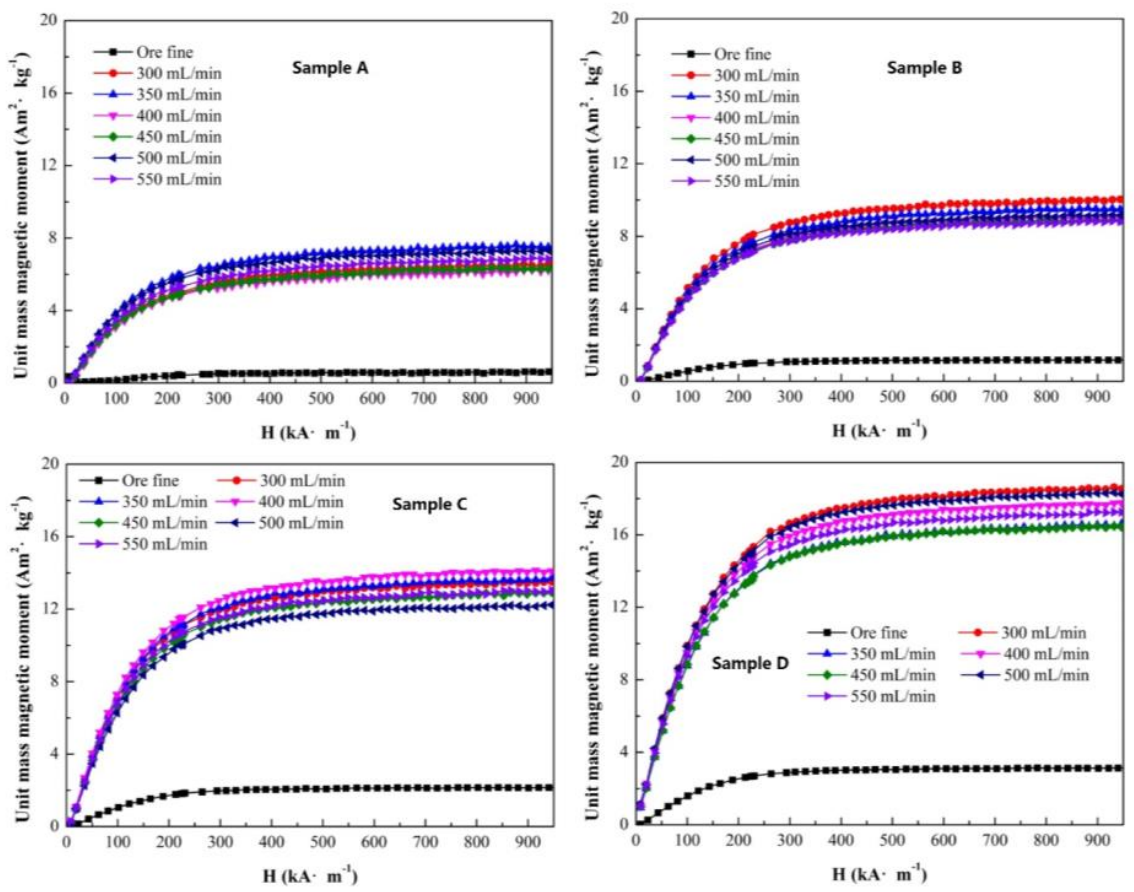

Figure 11. The unit mass magnetic moment of sample A to D with different gas flows. 
The different gas flows had a slight effect on iron grade and iron recovery of sample A to $\mathrm{D}$, as shown in Figure 12. For sample A and B, the iron grade fluctuated with a gas flow of $500 \mathrm{~mL} / \mathrm{min}$, then the iron grade declined at a gas flow of $550 \mathrm{~mL} / \mathrm{min}$. For sample $\mathrm{C}$ and $\mathrm{D}$, the iron grade increased with a gas flow of 300 to $500 \mathrm{~mL} / \mathrm{min}$. Additionally, the iron recovery of all the samples stabilized at about $66 \%$. Compared with roasting temperature, roasting time and $\mathrm{CO}$ ratio, the gas flow had the least effect on the magnetization roasting and separation index.
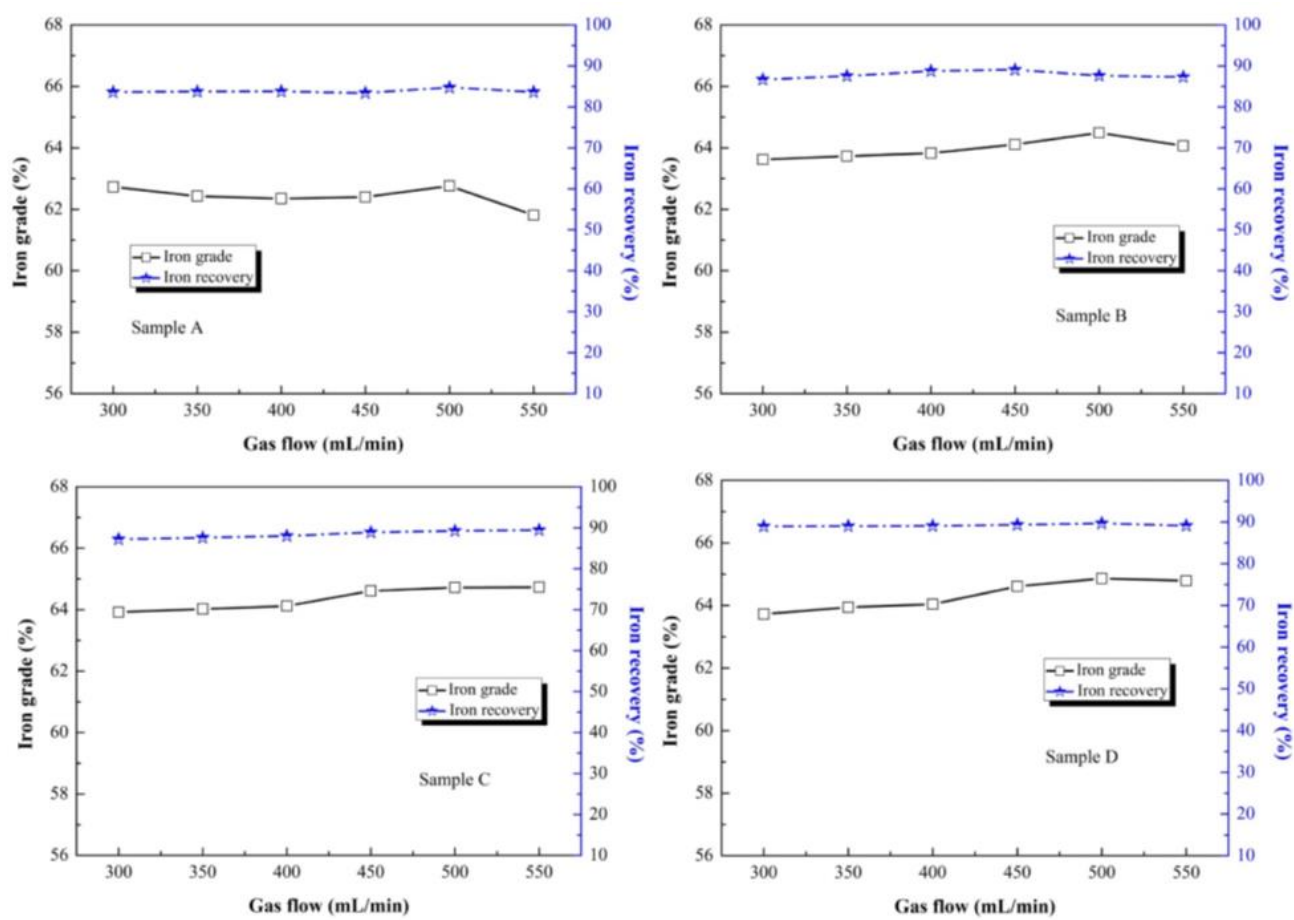

Figure 12. The iron grade and iron recovery of sample A to D with different gas flows.

\subsection{The Iron Phase Compositions after Magnetization Roasting}

According to the single-factor experiments in Section 3.1, the optimum magnetization roasting conditions were roasting temperature of $580^{\circ} \mathrm{C}$, roasting time of $5 \mathrm{~min}$, gas flow of $500 \mathrm{~mL} / \mathrm{min}$ and CO ratio of $30 \%$, and all the samples obtained an outstanding separation index through magnetic separation. With the optimum roasting conditions, the determined iron phase compositions of sample A to D are presented in Table 5, which can be used to analyze the transformation results from hematite to magnetite.

Table 5. The iron phase compositions and the content of Fe in iron phase of sample A to D after magnetization roasting.

\begin{tabular}{|c|c|c|c|c|c|c|c|}
\hline & Sample & $\begin{array}{c}\text { Fe in } \\
\text { Magnetite }\end{array}$ & $\begin{array}{c}\text { Fe in } \\
\text { Carbonate }\end{array}$ & $\begin{array}{c}\text { Fe in } \\
\text { Hematite }\end{array}$ & $\begin{array}{c}\text { Fe in } \\
\text { Sulfide }\end{array}$ & Fe in Silicate & Total Fe \\
\hline Content/wt\% & \multirow{2}{*}{ A } & 11.82 & 0.28 & 1.20 & 0.10 & 1.17 & 14.57 \\
\hline Percentage/\% & & 81.13 & 1.92 & 8.24 & 0.69 & 8.03 & 100.00 \\
\hline Content/wt $\%$ & \multirow[b]{2}{*}{ B } & 14.88 & 0.25 & 0.21 & 0.12 & 1.27 & 16.73 \\
\hline Percentage/\% & & 88.94 & 1.49 & 1.26 & 0.72 & 7.59 & 100.00 \\
\hline Content/wt\% & \multirow{2}{*}{$\mathrm{C}$} & 16.69 & 0.26 & 0.37 & 0.12 & 1.12 & 18.66 \\
\hline Percentage/\% & & 89.44 & 1.39 & 1.98 & 0.64 & 6.54 & 100.00 \\
\hline Content/wt $\%$ & \multirow{2}{*}{$\mathrm{D}$} & 18.76 & 0.27 & 0.46 & 0.14 & 1.18 & 20.81 \\
\hline Percentage/\% & & 90.15 & 1.30 & 2.21 & 0.67 & 5.67 & 100.00 \\
\hline
\end{tabular}


After magnetization roasting, the Fe in sample A to D was mainly present in the form of magnetite. For sample A, the content of Fe in magnetite increased to $11.82 \%$, which increased $11.51 \%$ units after roasting. Similarly, after magnetization roasting, the content of Fe in magnetite increased to $14.88 \%$ (sample B), $16.69 \%$ (sample C) and $18.76 \%$ (sample $\mathrm{D}$ ), and the content of $\mathrm{Fe}$ in magnetite grew in step with the original magnetite content. On the contrary, for sample A, the content of Fe in hematite declined to $1.20 \%$, which decreased $11.02 \%$ units after roasting. The increased contents of Fe in magnetite were $11.51 \%$ units (sample A), $11.78 \%$ units (sample B), $11.14 \%$ units (sample C) and $10.67 \%$ units (sample D), $11 \%$ units approximately. The increased contents of Fe in magnetite did not present a stable escalating trend with the increase in original magnetite. Therefore, the results also need further verification by magnetization roasting experiments, the separation index and magnetism conversion of sample A to D. Compared with the content of Fe in magnetite, the content of Fe in hematite declined to $0.21 \%$ (sample B), $0.37 \%$ (sample C) and $0.46 \%$ (sample D) after roasting. The content of Fe in carbonate of all the samples increased slightly. Additionally, the content of Fe in sulfide and silicate of all the samples declined slightly, because ignition loss and thermal decomposition occurred in all the samples simultaneously. The change in iron phase composition after roasting provided direct evidence of magnetization transformation.

\subsection{The Phase Transformations of Magnetization Roasted Products}

The phase transformation results of roasted samples are presented comprehensively, and XRD analysis was used to analyze the roasted products under different roasting times. The diffraction peaks of hematite, magnetite and quartz are presented in the XRD patterns of Figure 13a,c,e,g.

Due to the progressive increase in original magnetite content, some diffraction peaks of hematite were observed in sample A and sample B. For all the samples, the XRD pattern presented the dynamic phase transformation process during magnetization roasting. The hematite transformed to magnetite gradually with a roasting time from $1 \mathrm{~min}$ to $6 \mathrm{~min}$, which confirmed the reduction reactions of thermodynamic analysis. After 6 min of magnetization roasting, the number of diffraction peaks of magnetite increased with an increase in original magnetite content, which also agreed with the results of iron phase compositions of sample A to D. The $2 \theta$ range of $32^{\circ}$ to $38^{\circ}$ was selected to amplify and explore the iron phase transformations visually. As shown in Figure 13b,d,f,h, the diffraction peaks at $35.5^{\circ}$ were strengthened gradually during the roasting time from $1 \mathrm{~min}$ to $6 \mathrm{~min}$, which presented the magnetite. Meanwhile, the diffraction peaks at $32.2^{\circ}$ were weakened gradually during the roasting time from $1 \mathrm{~min}$ to $6 \mathrm{~min}$, which presented the hematite.

\subsection{The Original Magnetite Effect of Reduction Reaction under Optimum Roasting Conditions}

Under the optimum roasting conditions listed in Section 3.1, the difference in original magnetite content could affect the separation index and magnetism conversion rate of sample A to D. The separation indexes of sample A to D are presented in Figure 14a, and the iron grade and iron recovery of sample A to D showed a single growth trend. With magnetization roasting at the optimum conditions, the iron grade increased from $62.17 \%$ to $65.22 \%$, and the iron recovery increased from $84.02 \%$ to $92.02 \%$ after separation, when the original magnetite content of ore fines increased from $2.13 \%$ to $39.31 \%$, although the Fe masses of each sample were equal. Therefore, the separation index had direct correlation with the difference in original magnetite of sample A to D. Higher original magnetite content could promote phase transformation hematite and optimize the separation index. The magnetism conversion rate and the unit mass magnetic moment are presented in Figure $14 \mathrm{~b}$. With the equal Fe masses of sample A to D, the unit mass magnetic moment grew steadily, and the increase rate was not linear. Higher original magnetite content resulted in an increase in unit mass magnetic moment. In sample $\mathrm{D}$, the unit mass magnetic 
moment could reach $18.27 \mathrm{Am}^{2} \cdot \mathrm{kg}^{-1}$. The increase in unit mass magnetic moment was in favor of the separation index.

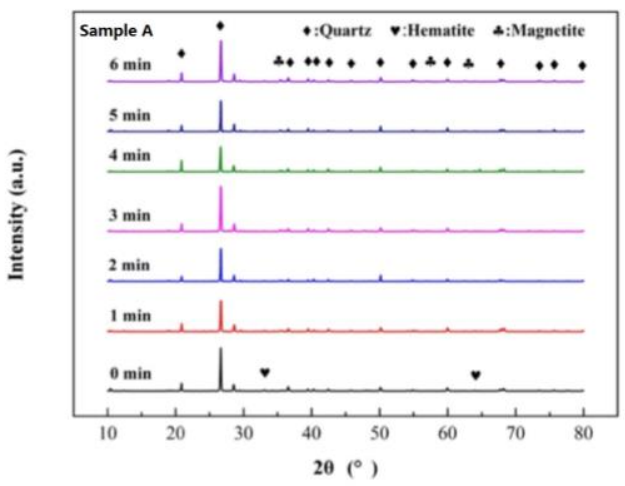

(a)

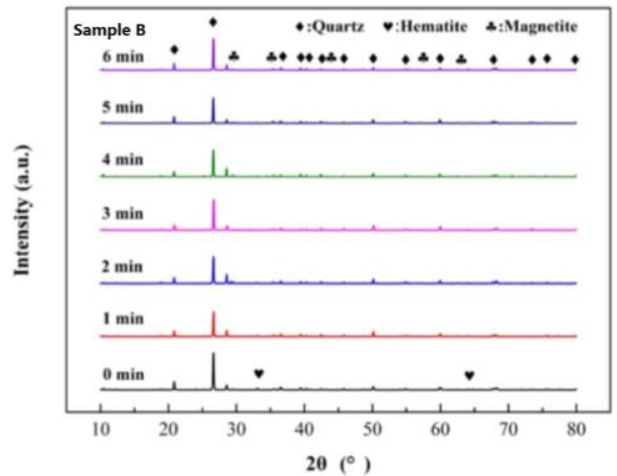

(c)

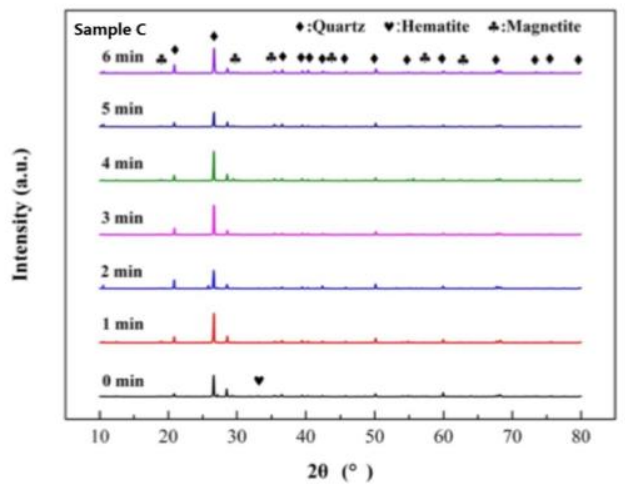

(e)

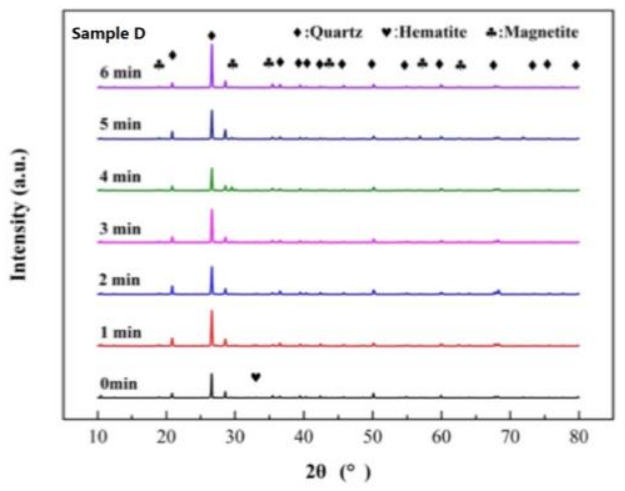

(g)

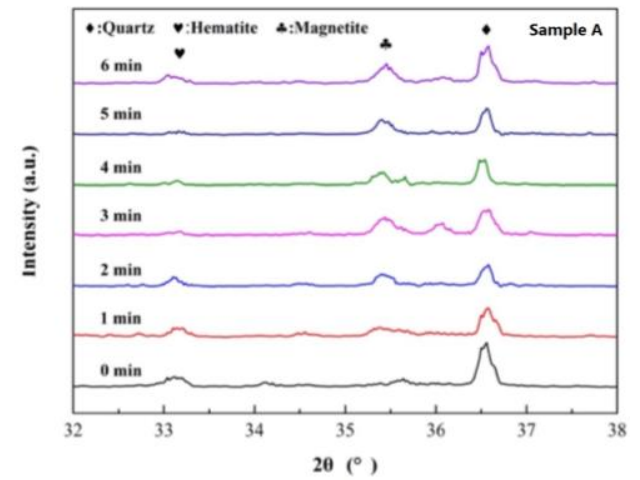

(b)

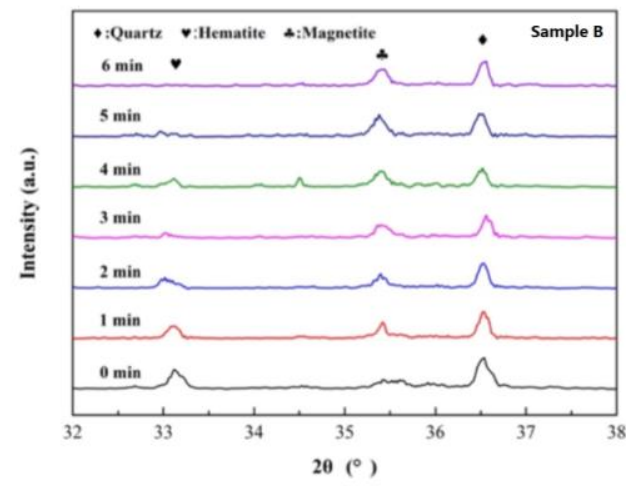

(d)

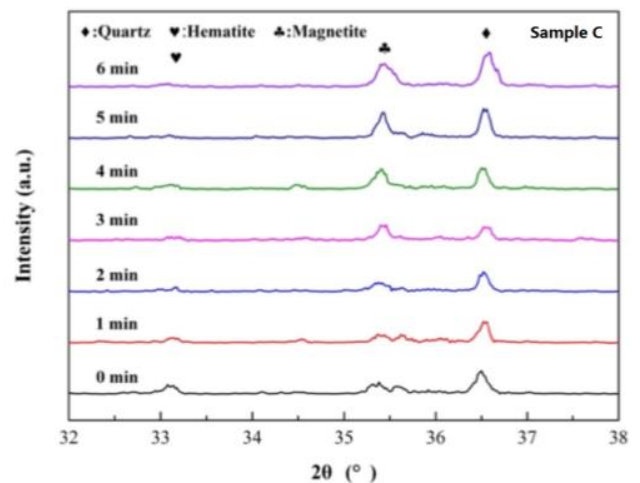

(f)

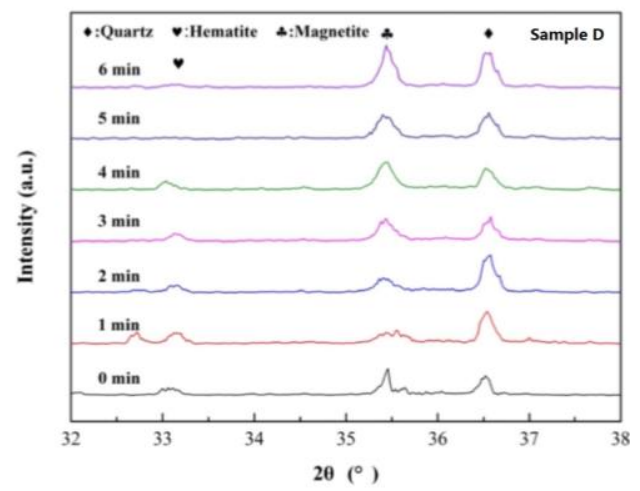

(h)

Figure 13. XRD patterns of sample A to D at different roasting times. $(\mathbf{a}, \mathbf{b})$ : Sample A, $(\mathbf{c}, \mathbf{d})$ : Sample B, (e,f): Sample C, (g,h): Sample D. 


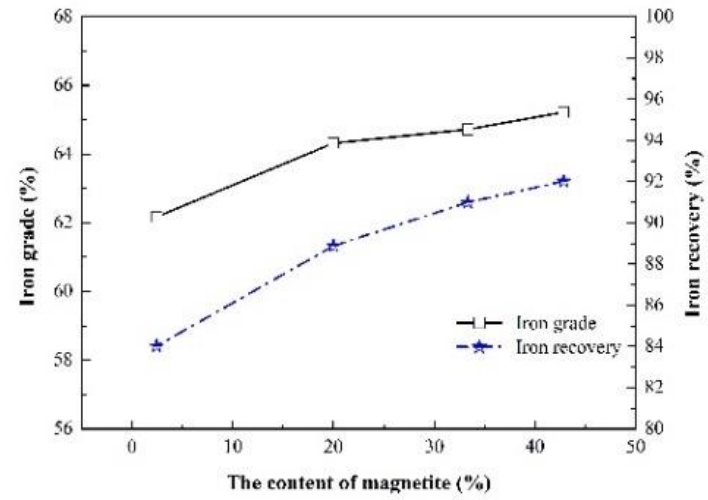

(a)

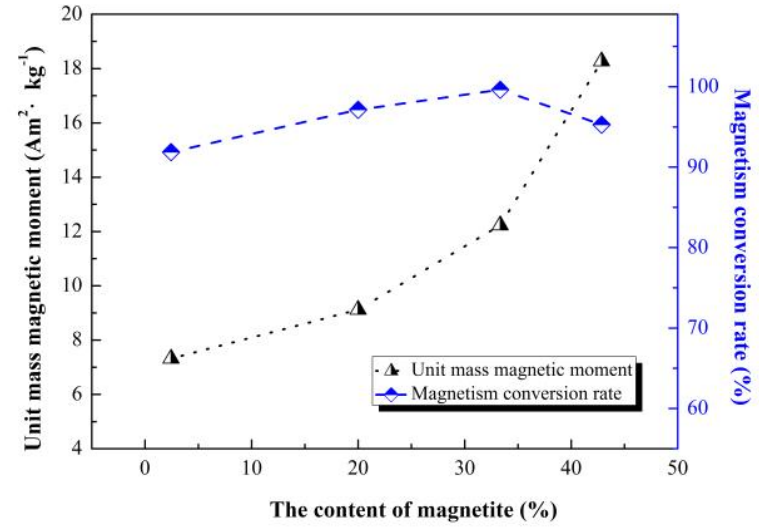

(b)

Figure 14. The separation index (a) and magnetism conversion (b) of sample A to D under optimum roasting conditions.

The overall trend of magnetism conversion rate was an increase with an increase in original magnetite content. The magnetism conversion rates of sample A to D were analyzed with the iron phase. When the content of Fe in original magnetite increased from $0.31 \%$ (sample A) to $5.55 \%$ (sample C), the magnetism conversion rate rose gradually. According to XRD analysis, the transformation from hematite to magnetite happened gradually, which could also provide magnetite crystal nuclei as the initial points for hematite reduction reactions. The initial points also promoted the hematite reduction reaction process. When the content of Fe in the original magnetite was $8.09 \%$ (sample D), the hematite transformation rate was quick, which caused a small quantity of hematite to become encased in the newly formed magnetite. Therefore, the magnetism conversion rate of sample D presented a slight decline compared with sample $C$. The magnetism conversion rate and the unit mass magnetic moment should be considered synthetically, and an appropriate magnetism conversion rate appeared at a content of Fe in original magnetite of $5.55 \%$. Therefore, when some original magnetite existed in iron ore (mainly hematite), only the separation index could not be used to evaluate the effect of the magnetization roasting process. To determine the effect of the magnetization roasting process reasonably, the magnetism conversion rate should also be considered in the suitable magnetization roasting conditions.

\subsection{The Interfacial Behavior of the Magnetite and Hematite Intergrowth}

In this study, the transformation of hematite to magnetite and the microcrack evolution process were captured continuously and recorded in situ by LSCM with confocal technology and 3D morphologic technology for the first time. The pores and cracks of lump ore produced by roasting were identified by the color depth of images. The lump ore $(5 \mathrm{~mm} \times 5 \mathrm{~mm})$ included two forms of single hematite and magnetite and hematite intergrowth. The transformation images of the magnetization roasting process of single hematite are shown in Figure 15, which were obtained with a roasting temperature of $500{ }^{\circ} \mathrm{C}$, gas flow of $30 \mathrm{~mL} / \mathrm{min}$ and $\mathrm{CO}$ ratio of $50 \%$.

Before magnetization roasting, the surface of the lump ore was relatively flat, and a small number of pores existed. When the roasting temperature rose to $500{ }^{\circ} \mathrm{C}$, the roasting process began with the injection of reductive gas. When the roasting time reached $64 \mathrm{~s}$, the surface color of the lump ore with single hematite changed. The transformation of hematite to magnetite occurred, and some microcracks appeared in the lower left corner of the lump ore. The microcrack evolution process was present during the roasting time of $64 \mathrm{~s}$ to $326 \mathrm{~s}$, as shown in Figure 15b-e. The major microcracks were formed around existing pores by protogenesis or produced by roasting, and the microcrack evolution is labeled in Figure 15. When the roasting time reached $206 \mathrm{~s}$, new microcracks were extended further. The transformation of hematite to magnetite developed from the surface to inside the lump 
ore. When the roasting time reached $326 \mathrm{~s}$, the microcracks were further extended to inside the lump ore.

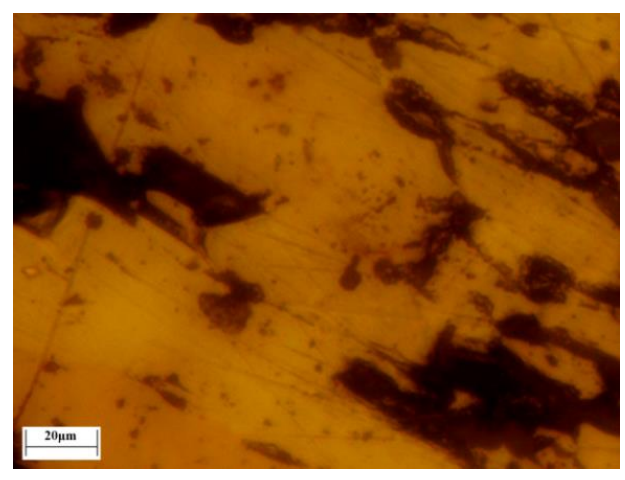

(a)

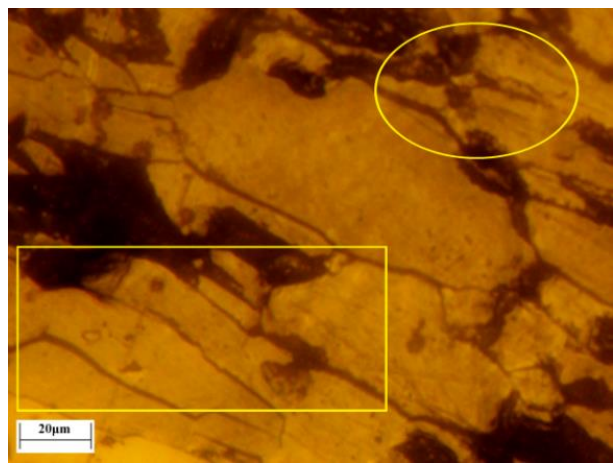

(c)

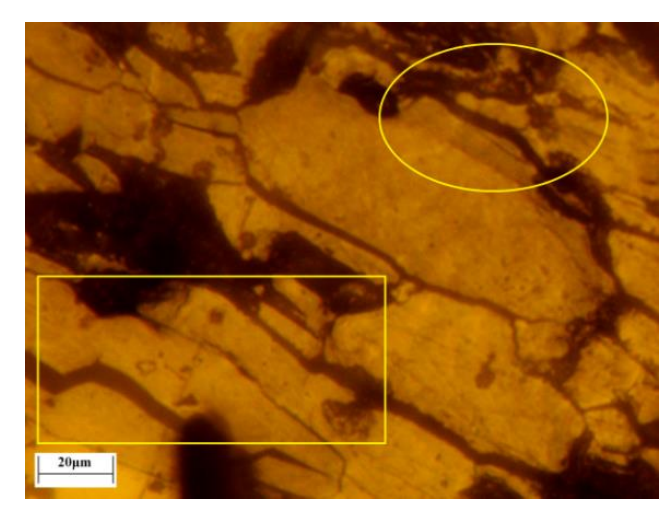

(e)

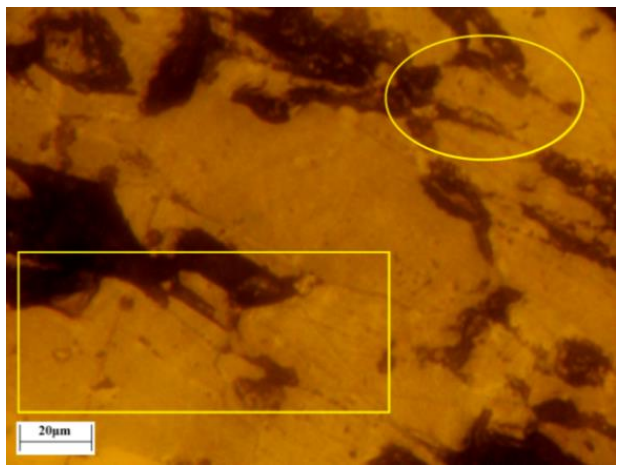

(b)

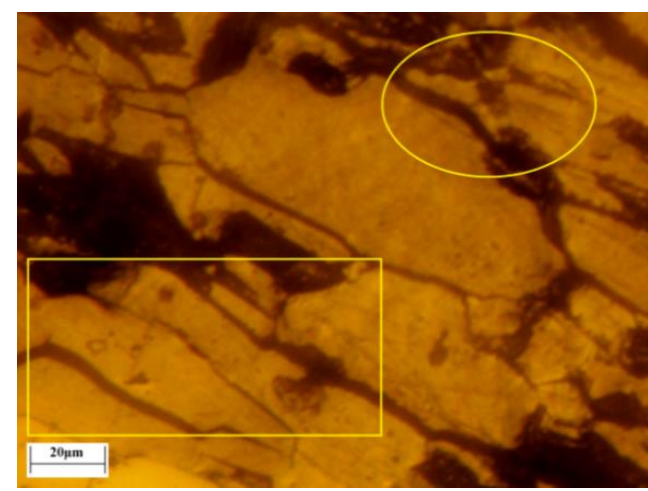

(d)

Figure 15. The continuous magnetization roasting process of single hematite. (a) $500{ }^{\circ} \mathrm{C} ; 0 \mathrm{~s}$, (b) $500{ }^{\circ} \mathrm{C} ; 64 \mathrm{~s},(\mathbf{c}) 500{ }^{\circ} \mathrm{C} ; 114 \mathrm{~s},(\mathrm{~d}) 500{ }^{\circ} \mathrm{C} ; 206 \mathrm{~s},(\mathbf{e}) 500{ }^{\circ} \mathrm{C} ; 326 \mathrm{~s}$.

Firstly, after roasting, the phase transformation was distinguished by the color change of the lump ore surface according to the color contrast of Figure 16a,c,e and Figure 16b,d,f. As shown in Figure $16 \mathrm{~b}, \mathrm{~d}, \mathrm{f}$, the location of hematite transformation to magnetite mainly appeared at the naturally uneven areas and protogenetic pore edges. As the naturally uneven areas and protogenetic pore edges could meet reductive gas first, they had a greater probability to become the active sites of the original reduction reaction. Secondly, some of the microcrack evolution began from the edges of magnetite and hematite. From the beginning of mineralization, the tightness of magnetite and hematite was different compared to that of a single mineral. The slight microcracks also provided the original reduction reaction 
sites. Additionally, these microcracks evolved into the major microcracks gradually, which accelerated the reduction reaction further. This was the most important reason for original magnetite improving the iron ore reduction reaction, which was observed by in situ and continuous image capture and confocal technology and 3D morphologic technology images of magnetite and hematite intergrowth for the first time.

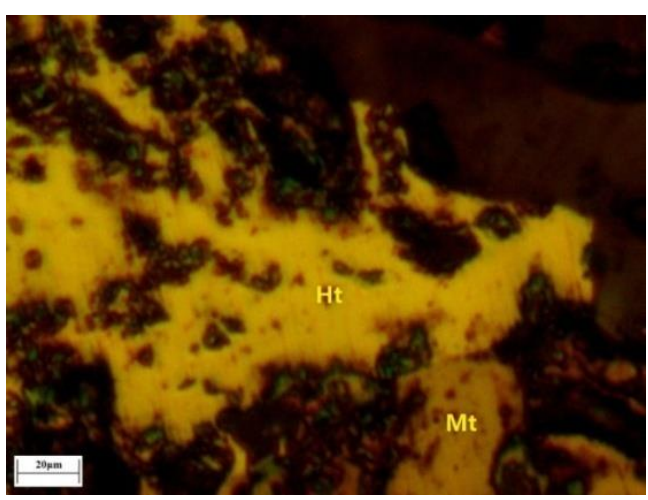

(a)

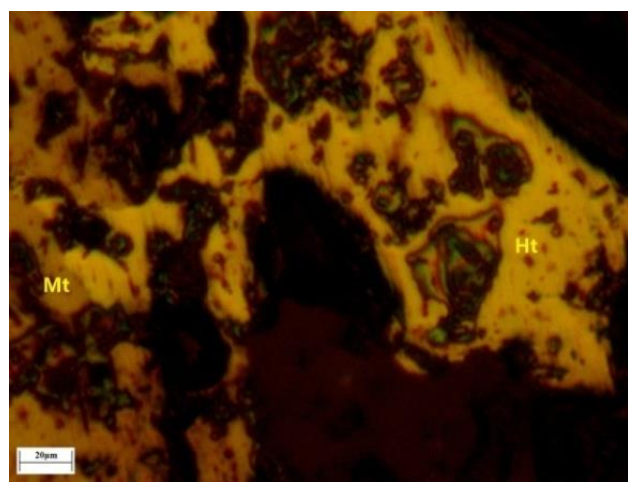

(c)

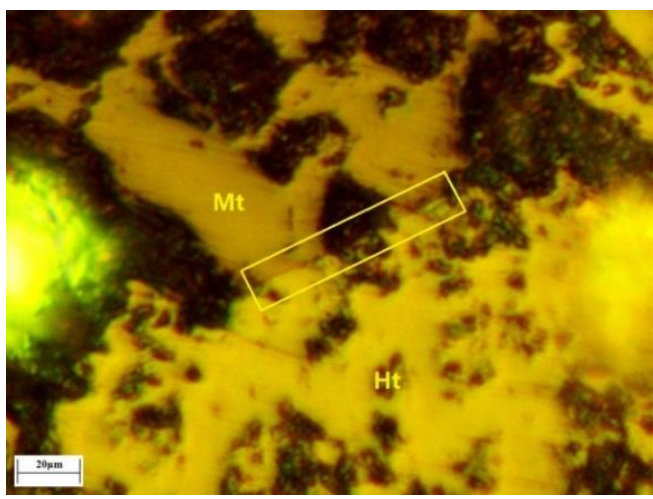

(e)

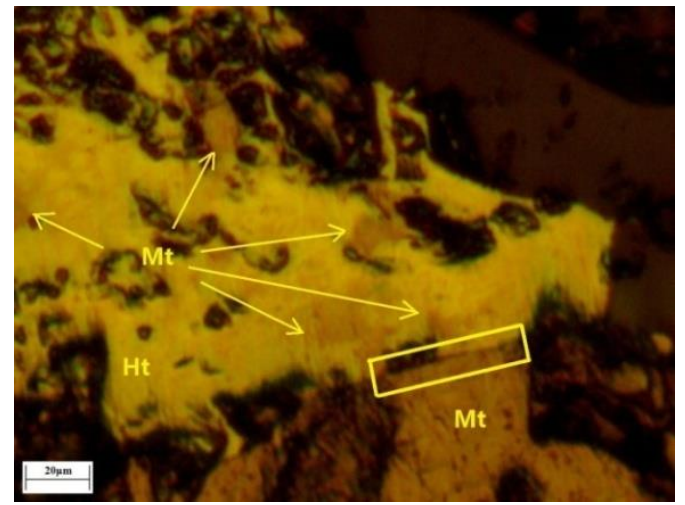

(b)

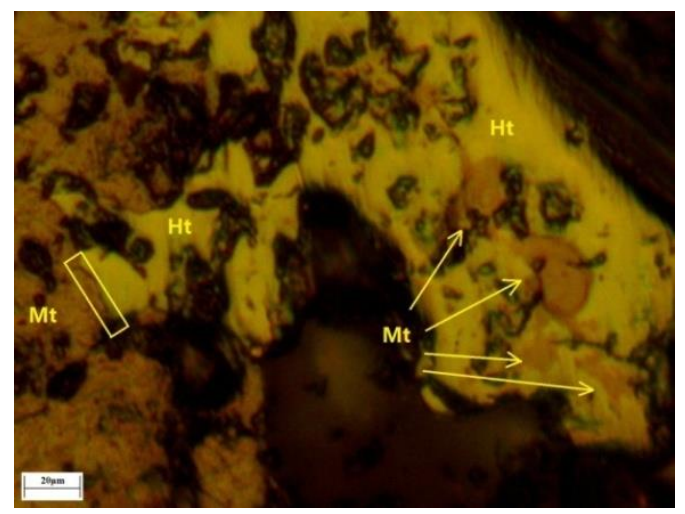

(d)

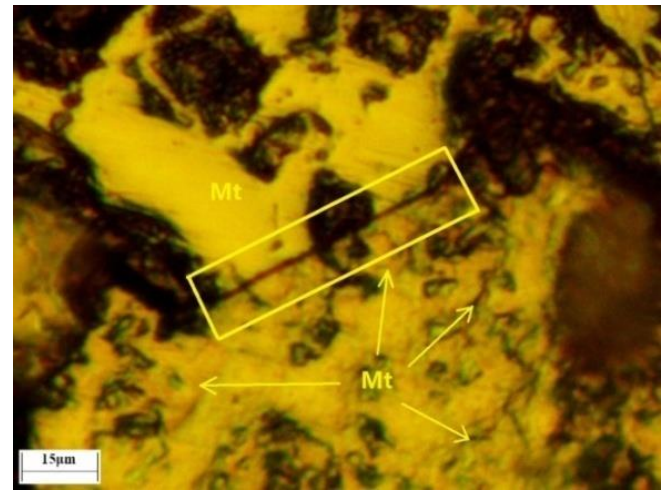

(f)

Figure 16. The continuous magnetization roasting process of magnetite and hematite intergrowth. (a) Site 1; $0 \mathrm{~s}$, (b) Site 1; $300 \mathrm{~s}$, (c) Site 2; 0 s, (d) Site 2; 300 s, (e) Site 3; 0 s, (f) Site 3; 300 s.

The schematic diagram of mechanism analysis is presented in Figure 17. For single hematite, after cutting, the reduction reaction occurred at the surface layer of the lump ore. Then, the some microcracks evolved from the surface layer to the inside. For the magnetite and hematite intergrowth, some microcracks evolved from the surface layer and the edges 
of magnetite and hematite gradually, and further reduction reactions were produced inside the lump ore. Therefore, the microcrack evolution had a direct connection with the efficient improvement during the ore reduction process.

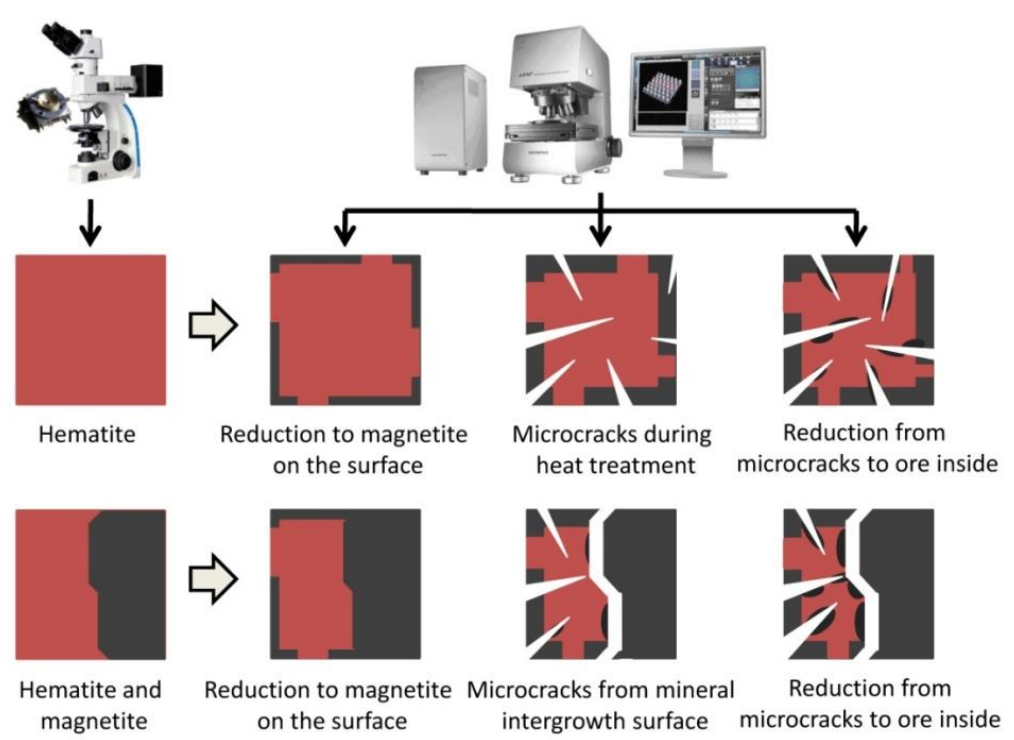

Figure 17. The schematic diagram of mechanism analysis.

\section{Conclusions}

In this research, the improvement and reaction mechanism of original magnetite on the iron ore reduction reaction in the magnetization roasting process were explored by ore fines and lump ores. With an equal Fe mass of ore fine in each sample, higher original magnetite content of the samples could promote phase transformation from hematite to magnetite, increase the unit mass magnetic moment and optimize the separation index of roasted samples after low-intensity magnetic separation. Additionally, the magnetism conversion rate could guide more reasonable magnetization roasting reaction conditions. Through in situ and continuous image capture, it was found that the naturally uneven areas and protogenetic pore edges could meet the reductive gas first, and these areas and edges had a greater probability to become the original reduction reaction sites first. Additionally, a some microcrack evolution was generated from the edges of magnetite and hematite. The slight microcracks provided the original reduction reaction sites and accelerated the reduction reaction further, which was the main mechanism of original magnetite improving the iron ore reduction reaction.

Author Contributions: Conceptualization, P.G.; methodology, P.G., W.Z. and B.Z.; software, W.Z.; validation, B.Z. and Z.T.; formal analysis, B.Z.; data curation, W.Z.; writing-original draft preparation, B.Z.; writing-review and editing, B.Z.; visualization, B.Z.; supervision, P.G.; project administration, Z.T.; funding acquisition, B.Z. All authors have read and agreed to the published version of the manuscript.

Funding: This research was funded by the National Natural Science Foundation of China, grant numbers 52004056 and 51734005, and the National Key Research and Development Program of China, grant number 2018YFC1901902.

Institutional Review Board Statement: Not applicable.

Informed Consent Statement: Not applicable.

Data Availability Statement: The data presented in this study are available on request from the corresponding author. The data are not publicly available due to the terms of the project.

Conflicts of Interest: The authors declare no conflict of interest. 


\section{References}

1. Sun, Y.; Han, Y.; Gao, P.; Yu, J. Size Distribution Behavior of Metallic Iron Particles in Coal-Based Reduction Products of an Oolitic Iron Ore. Miner. Process. Extr. Met. Rev. 2014, 36, 249-257. [CrossRef]

2. Yu, J.; Han, Y.; Li, Y.; Gao, P.; Sun, Y. Separation and recovery of iron from a low-grade carbonate-bearing iron ore using magnetizing roasting followed by magnetic separation. Sep. Sci. Technol. 2017, 52, 1768-1774. [CrossRef]

3. Chun, T.; Zhu, D.; Pan, J. Simultaneously Roasting and Magnetic Separation to Treat Low Grade Siderite and Hematite Ores. Miner. Process. Extr. Met. Rev. 2015, 36, 223-226. [CrossRef]

4. Li, Y.J.; Zhang, Q.; Yuan, S.; Yin, H. High-efficiency extraction of iron from early iron tailings via the suspension roasting-magnetic separation. Powder Technol. 2021, 379, 466-477. [CrossRef]

5. Sun, Y.; Zhang, Q.; Han, Y.; Gao, P.; Li, G. Comprehensive Utilization of Iron and Phosphorus from High-Phosphorus Refractory Iron Ore. JOM 2017, 70, 144-149. [CrossRef]

6. Zhang, X.; Han, Y.; Sun, Y.; Li, Y. Innovative utilization of refractory iron ore via suspension magnetization roasting: A pilot-scale study. Powder Technol. 2019, 352, 16-24. [CrossRef]

7. Zhou, W.; Sun, Y.; Han, Y.; Gao, P.; Li, Y. Recycling iron from oolitic hematite via microwave fluidization roasting and magnetic separation. Miner. Eng. 2021, 164, 106851. [CrossRef]

8. Nunna, V.; Hapugoda, S.; Pownceby, M.I.; Sparrow, G.J. Beneficiation of low-grade, goethite-rich iron ore using microwaveassisted magnetizing roasting. Miner. Eng. 2021, 166, 106826. [CrossRef]

9. Matiolo, E.; Couto, H.J.B.; Lima, N.; Silva, K.; de Freitas, A.S. Improving recovery of iron using column flotation of iron ore slimes. Miner. Eng. 2020, 158, 106608. [CrossRef]

10. Li, L.; Hao, H.; Yuan, Z.; Liu, J. Molecular dynamics simulation of siderite-hematite-quartz flotation with sodium oleate. Appl. Surf. Sci. 2017, 419, 557-563. [CrossRef]

11. Quast, K. An investigation of the flotation minimum in the oleate flotation of hematite under alkaline conditions. Miner. Eng. 2017, 113, 71-82. [CrossRef]

12. Vidyadhar, A.; Ari, V.; Bhagat, R. Adsorption mechanism of mixed collector systems on hematite flotation. Miner. Eng. 2012, 26, 102-104. [CrossRef]

13. Rath, S.S.; Sahoo, H.; Das, S.; Das, B.; Mishra, B. Influence of band thickness of banded hematite quartzite (BHQ) ore in flotation. Int. J. Miner. Process. 2014, 130, 48-55. [CrossRef]

14. Shrimali, K.; Atluri, V.; Wang, Y.; Bacchuwar, S.; Wang, X.; Miller, J.D. The nature of hematite depression with corn starch in the reverse flotation of iron ore. J. Colloid Interface Sci. 2018, 524, 337-349. [CrossRef] [PubMed]

15. Yang, S.; Li, C.; Wang, L. Dissolution of starch and its role in the flotation separation of quartz from hematite. Powder Technol. 2017, 320, 346-357. [CrossRef]

16. Shrimali, K.; Miller, J.D. Polysaccharide Depressants for the Reverse Flotation of Iron Ore. Trans. Indian Inst. Met. 2016, 69, 83-95. [CrossRef]

17. Song, S.; Lu, S.; Lopez-Valdivieso, A. Magnetic separation of hematite and limonite fines as hydrophobic flocs from iron ores. Miner. Eng. 2002, 15, 415-422. [CrossRef]

18. Tripathy, S.K.; Singh, V.; Murthy, Y.R.; Banerjee, P.K.; Suresh, N. Influence of process parameters of dry high intensity magnetic separators on separation of hematite. Int. J. Miner. Process. 2017, 160, 16-31. [CrossRef]

19. Tripathy, S.K.; Banerjee, P.K.; Suresh, N. Separation analysis of dry high intensity induced roll magnetic separator for concentration of hematite fines. Powder Technol. 2014, 264, 527-535. [CrossRef]

20. Yu, J.; Han, Y.; Li, Y.; Gao, P. Beneficiation of an iron ore fines by magnetization roasting and magnetic separation. Int. J. Miner. Process. 2017, 168, 102-108. [CrossRef]

21. Tang, Z.; Gao, P.; Li, Y.; Han, Y.; Li, W.; Butt, S.; Zhang, Y. Recovery of iron from hazardous tailings using fluidized roasting coupling technology. Powder Technol. 2020, 361, 591-599. [CrossRef]

22. Sun, Y.S.; Zhang, X.L.; Han, Y.X.; Li, Y.J. A new approach for recovering iron from iron ore tailings using suspension magnetization roasting: a pilot-scale study. Powder Technol. 2020, 361, 571-580. [CrossRef]

23. Yuan, S.; Liu, X.; Gao, P.; Han, Y.X. A semi-industrial experiment of suspension magnetization roasting technology for separation of iron minerals from red mud. J. Hazard. Mater. 2020, 394, 122579. [CrossRef]

24. Li, Y.-J.; Wang, R.; Han, Y.-X.; Wei, X.-C. Phase transformation in suspension roasting of oolitic hematite ore. J. Central South Univ. 2015, 22, 4560-4565. [CrossRef]

25. Ponomar, V.; Dudchenko, N.; Brik, A. Reduction roasting of hematite to magnetite using carbohydrates. Int. J. Miner. Process. 2017, 164, 21-25. [CrossRef]

26. Sun, Y.; Zhu, X.; Han, Y.; Li, Y.; Gao, P. Iron recovery from refractory limonite ore using suspension magnetization roasting: A pilot-scale study. J. Clean. Prod. 2020, 261, 121221. [CrossRef]

27. Sun, Y.; Zhu, X.; Han, Y.; Li, Y. Green magnetization roasting technology for refractory iron ore using siderite as a reductant. J. Clean. Prod. 2019, 206, 40-50. [CrossRef]

28. Yu, J.; Han, Y.; Li, Y.; Gao, P. Recovery and separation of iron from iron ore using innovative fluidized magnetization roasting and magnetic separation. J. Min. Met. Sect. B Met. 2018, 54, 21-27. [CrossRef]

29. Yu, J.; Han, Y.-X.; Li, Y.-J.; Gao, P. Growth behavior of the magnetite phase in the reduction of hematite via a fluidized bed. Int. J. Miner. Met. Mater. 2019, 26, 1231-1238. [CrossRef] 
30. Chen, J.; Zhang, R.; Simmonds, T.; Hayes, P.C. Microstructural Changes and Kinetics of Reduction of Hematite to Magnetite in CO/CO2 Gas Atmospheres. Met. Mater. Trans. A 2019, 50, 2612-2622. [CrossRef]

31. Strezov, V.; Evans, T.J.; Zymla, V.; Strezov, L. Structural deterioration of iron ore particles during thermal processing. Int. J. Miner. Process. 2011, 100, 27-32. [CrossRef]

32. Yuan, S.; Zhou, W.; Han, Y.; Li, Y. Separation of manganese and iron for low-grade ferromanganese ore via fluidization magnetization roasting and magnetic separation technology. Miner. Eng. 2020, 152, 106359. [CrossRef]

33. Ponomar, V.; Dudchenko, N.; Brik, A. Synthesis of magnetite powder from the mixture consisting of siderite and hematite iron ores. Miner. Eng. 2018, 122, 277-284. [CrossRef]

34. Zhang, Y.; Li, H.; Yu, X. Recovery of iron from cyanide tailings with reduction roasting-water leaching followed by magnetic separation. J. Hazard. Mater. 2012, 213-214, 167-174. [CrossRef] [PubMed]

35. Tang, Z.D.; Zhang, Q.; Sun, Y.S.; Gao, P.; Han, Y.X. Pilot-scale extraction of iron from flotation tailings via suspension magnetization roasting in a mixture of $\mathrm{CO}$ and $\mathrm{H}_{2}$ followed by magnetic separation. Resour. Conserv. Recycl. 2021, 172, 105680. [CrossRef] 